Research, part of a Special Feature on Telecoupling: A New Frontier for Global Sustainability

\title{
Smallholder telecoupling and potential sustainability
}

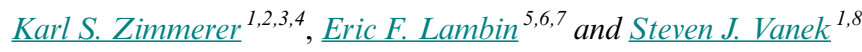

\begin{abstract}
Smallholders are crucial for global sustainability given their importance to food and nutritional security, agriculture, and biodiversity conservation. Worldwide smallholders are subject to expanded telecoupling whereby their social-ecological systems are linked to large-scale socioeconomic and environmental drivers. The present research uses the synthesis of empirical evidence to demonstrate smallholder telecoupling through the linkages stemming from the global-level integration of markets (commodity, labor, finance), urbanization, governance, and technology. These telecoupling forces are often disadvantageous to smallholders while certain conditions can contribute to the potential sustainability of their social-ecological systems. Case studies were chosen to describe sustainability opportunities and limits involving smallholder production and consumption of high-agrobiodiversity Andean maize amid telecoupled migration (Bolivia), the role of international eco-certification in smallholder coffee-growing and agroforests (Colombia), smallholder organic dairy production in large-scale markets and technology transfer (upper Midwest, U.S.A.), and smallholders' global niche commodity production of argan oil (Morocco). These case studies are used to identify the key challenges and opportunities faced by smallholders in telecoupling and to develop a conceptual framework. This framework specifies the integrated roles of global systems together with influential public and private institutions operating at multiple scales including the national level. The framework also integrates the local dynamics of smallholders' multiple land use units and their socioeconomic and environmental variation. Spatial spillover effects in smallholder landscapes are an additional element. This framework further establishes the unRomantic, nonteleological, and antifetishistic view of smallholders. It provides specific insights on the multilevel dynamics of smallholder telecoupling and potential sustainability opportunities that can strengthen livelihoods, biodiversity conservation, and food and nutritional security. These insights are concluded to be valuable to environmental, agricultural, and food scientists and scholars (both biogeophysical sciences and social sciences), policy makers, institutional analysts, development specialists and practitioners, social justice activists, and others seeking to advance global sustainability including sustainable development.
\end{abstract}

Key Words: agrobiodiversity; argan; biodiversity; coffee; eco-certification; food security; globalization; maize; nutritional security; organic dairy; private and public institutions; resilience; smallholders; small-scale agriculture; social-ecological systems; spillovers; sustainability; telecoupling

\section{INTRODUCTION: EXPANDED SMALLHOLDER TELECOUPLING}

Telecoupling is the linking of local and regional social-ecological systems to large-scale, networked socioeconomic and environmental drivers operating at a distance (Liu et al. 2013, 2015, Eakin et al. 2014, Verburg et al. 2015). The telecoupled linkages are driven through the demand of global "receiving systems" such as commodity, finance, and labor markets. Rapidly expanding telecoupled systems are also propelled through urbanization (Seto et al. 2012, Seto and Ramankutty 2016) and the governance-knowledge nexus of policy and management that is increasingly global (Zimmerer 2006, Liu et al. 2013, Zimmerer et al. 2015, Lenschow et al. 2016). To date the "sending systems" assessed in telecoupling analysis are large-scale forests (Lambin and Meyfroidt 2011, Meyfroidt et al. 2013) as well as agricultural plantations (DeFries et al. 2013, Baird and Fox 2015, Friis et al. 2016a,b, Friis and Nielsen 2016, 2017, Baird 2017, Sun et al. 2017). The telecoupled social-ecological sending system is often focused on large-scale spatial occurrence, e.g., the large acreage of telecoupled soy fields in the Brazilian soy boom, that can be evaluated using remote sensing images and public data.

Focus on the social-ecological systems of smallholders is a significant gap to date in the burgeoning literature on telecoupling and global sustainability. Smallholders are crucial to resource management (often in marginal environments that are biodiversity rich and vital to freshwater systems) and food growing including issues of food and nutritional security (Zimmerer 2013, Zimmerer et al. 2015, Samberg et al. 2016, Herrero et al. 2017). Smallholders are also increasingly recognized as demographically, environmentally, and socially important both at the global scale and within diverse national contexts (HLPE 2013, IFAD 2013, Van Vliet et al. 2015, Cárdenas et al. 2017, Cohn et al. 2017). Yet to date their potential contributions to sustainability, and limits thereof, have not been a focus of the telecoupling perspective. In addition to the predominant emphasis mentioned above, a widespread assumption of the impending demise of smallholders also fuels this oversight (discussed in Zimmerer et al. 2015, Zimmerer and Vanek 2016).

Smallholders are defined as resource users whose individual and household-level capital and land allocations are minor relative to predominant land systems (Turner and Brush 1987, Netting 1993). Globally the category of smallholders has been defined as those accessing resource areas less than 2.0 hectares (HLPE 2013, IFAD 2013). Country-specific estimations show this definition varies at the national level from 0.2 ha (China) and 1.0 ha (Ethiopia, India) to 5.0 ha (Netherlands, Brazil) and 20.0 ha

${ }^{1}$ GeoSyntheSES Laboratory, Department of Geography, Pennsylvania State University, University Park, PA, USA, ${ }^{2}$ Earth and Environmental Systems Institute (EESI), Pennsylvania State University, University Park, PA, USA, ${ }^{3}$ Department of Rural Sociology, Agricultural Economics, and Education, Pennsylvania State University, University Park, PA, USA, ${ }^{4}$ Department of Geography, Universidad Autónoma de Madrid, Madrid, Spain, ${ }^{5}$ School of Earth, Energy, and Environmental Sciences, Stanford University, Palo Alto, CA, USA, ${ }^{6}$ Woods Institute for the Environment, Stanford University, Palo Alto, CA, USA, ${ }^{7}$ Georges Lemaître Earth and Climate Research Centre, Earth and Life Institute, Université catholique de Louvain, Louvain-la-Neuve, Belgium, ${ }^{8}$ Department of Soil and Crop Sciences, Colorado State University, Fort Collins, CO, USA 
(USA; van Vliet et al. 2015), while significant new debate continues concerning estimation techniques (Meyfroidt 2017). Estimates of current global populations range from 2.0 billion to 2.5 billion smallholders (HLPE 2013:27-28, IFAD 2013:1). Smallholders currently comprise a sizeable majority of the word's rural population (Fig. 1) with upward of $75 \%$ in Asia, Africa, and Latin America. Smallholders are thus demographically important in global resource use and the corresponding issues of sustainability and sustainable development, including agri-food sustainability, even while their roles are minor at the level of individual units.

Fig. 1. Principal geographic distribution of global smallholder populations (2010) with comparisons to global rural and periurban populations $(1990,2010$; LAC refers to Latin America and the Caribbean. The Global North includes Australia, Canada, Europe, New Zealand, and the United States. Methods: Smallholder and rural populations were estimated using major data sources on global population (HLPE 2013, World Bank 2014). The HLPE uses the definition of smallholders as agricultural land users with holdings smaller than 2 hectares. Periurban populations were estimated by calculating using GIS buffer layers of radius set in direct proportion to the city population and the gridded global population (SEDAC gridded population of the world, V.3; http://sedac.ciesin.columbia.edu/data/collection/gpw-v3)

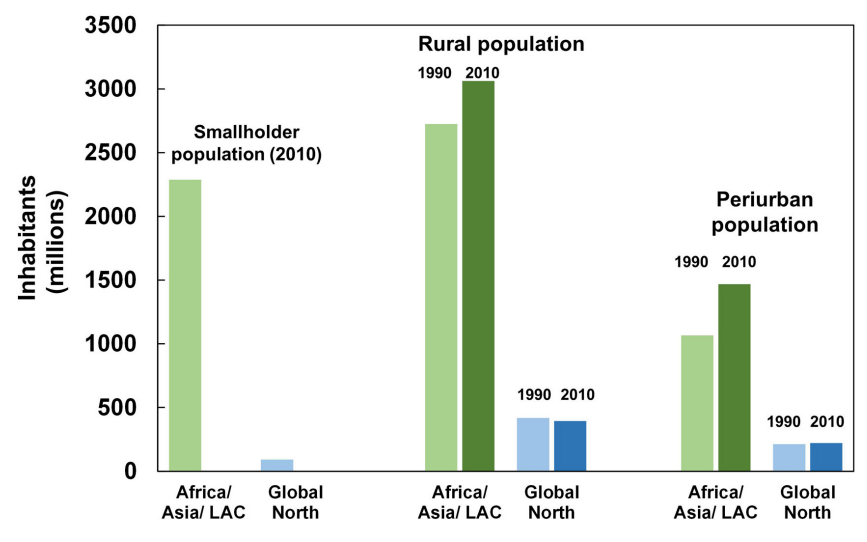

Globally, the demographic presence of smallholders remains significant notwithstanding the powerful, marginalizing counterforces of land and resource grabs as well as the corporate industrialization of agri-food and resource sectors (Wolford et al. 2013, Baird and Fox 2015, Baird 2017). Smallholders are a large, persistent, and internally diverse group that defies overly narrow definition and that overlaps but is not equivalent to the category of family farmers (Turner and Brush 1987, Netting 1993, Darnhofer 2014, van Vliet et al. 2015, Graeub et al. 2016, Lowder et al. 2016). Telecoupled flows linked to smallholders range from Global North-Global South linkages to Global South-Global South connections and region-scale integration (Gasparri et al. 2016). The global analysis of smallholder social-ecological systems, including this research, are expanding rapidly in the wake of the UN's "Year of the Family Farm" (2014).
Smallholder social-ecological systems are estimated to cover at least 10 million ha worldwide (Altieri 2004). Although considered marginal to modern agriculture, the social-ecological systems of smallholders encompass a high diversity of both upland and lowlying habitats essential to global biodiversity, water and biogeochemical cycles, and potential resilience vis-à-vis climate change (Perfecto and Vandermeer 2002, Mutersbaugh 2006, Cumming et al. 2013). They support the majority of the world's food plant and livestock biodiversity being currently produced and consumed (Zimmerer and de Haan 2017). Smallholder areas offer critical interfaces with wildlands and wildlife habitat of global importance (Zimmerer 2006). Socially, their food production is a vital "backbone of global food security" (Tscharntke et al. 2012:53, Cárdenas et al. 2017; see also Rudel and Meyfroidt 2014). Addressing global priorities on poverty, food, health, and the environmental, such as those stipulated in the new UN Sustainable Development goals, requires attention to the needs and capacities of smallholders (Barrett et al. 2011, Zimmerer et al. 2015, Zimmerer 2017).

Examining smallholder livelihoods and ecological systems amid telecoupling leads this research to incorporate the approach of social-ecological systems (SES; Ostrom 2009). SES highlight the connected roles of resources, users, and governance, and thus provide an approach well-suited to the examination of smallholder telecoupling. To address livelihood and development dimensions, this research also integrates the approaches of sustainable development studies and political ecology (Zimmerer 2014, Zimmerer et al. 2015, Zimmerer and Vanek 2016). In recognizing extra-local interactions, this integrated approach highlights the relevance of conditions that are both internal and external to the smallholder individual and household per se. It also engages approaches, e.g., biodiversity conservation and agrifood systems (Brondizio et al. 2016, Baird 2017, Kok et al. 2017, Zimmerer and de Haan 2017) demonstrating that nearly every social-ecological system, however remote and small scale, is coupled to global forces.

The present research expands these points to examine how smallholders are increasingly situated in influential contexts of public and private institutions operating at various scales. These institutional contexts, as well as local-level social networks and organizations, combine to influence household-level decision making about land and resources (Barrett 2008). Our telecoupling perspective thus contrasts the once predominant conceptual model of smallholder land use as "traditional agriculture" tending toward the autarkic (per previous landmark ecological assessments). Instead smallholders typically admix traditional resource use with modern techniques (Plieninger and Bieling 2012).

Telecoupling, like globalization in general, can be expected to result in a range of interactions with smallholder social-ecological systems (SES). It is important, therefore, to develop an expanded framework that can enable analysis of the opportunities for sustainability. To do so we first describe the rapid expansion of smallholder telecoupling. We present diverse case studies chosen to illustrate telecoupled, smallholder social-ecological systems that have undergone major changes demonstrating potential sustainability as well as notable limits. To distill these case studies, 
Table 1. Examples of influential telecoupling linkages to smallholder social-ecological systems (SES).

\begin{tabular}{|c|c|c|c|c|c|}
\hline General Linkage & $\begin{array}{l}\text { Drivers of the } \\
\text { Linkage }\end{array}$ & Expansion & Research & Countries & Smallholder SES \\
\hline $\begin{array}{l}\text { Global integration } \\
\text { and fiscalization of } \\
\text { industrial agri-food }\end{array}$ & $\begin{array}{l}\text { Global commodity markets } \\
\text { and trade (e.g., WTO, GATT); } \\
\text { Niche commodities; "Cheap } \\
\text { food" policies }\end{array}$ & $\begin{array}{l}\text { Late } 1980 \mathrm{~s}- \\
\text { present }\end{array}$ & $\begin{array}{l}\text { Bebbington and } \\
\text { Batterbury 2001, } \\
\text { Vorley 2001, } \\
\text { Challies 2008 }\end{array}$ & $\begin{array}{l}\text { Global; Brazil, Chile, } \\
\text { Mexico, Niger, Peru, } \\
\text { South Africa, } \\
\text { Thailand }\end{array}$ & $\begin{array}{l}\text { Soil and water resources; forests and } \\
\text { woodlands; biodiversity (both } \\
\text { "wild" and agrobiodiversity ) }\end{array}$ \\
\hline $\begin{array}{l}\text { Globalization of } \\
\text { international labor } \\
\text { markets (migration) }\end{array}$ & "Cheap labor" policies & 1995-present & $\begin{array}{l}\text { Jones } 1998 \text {, Castles } \\
\text { et al. 2013, } \\
\text { Zimmerer and } \\
\text { Vanek } 2016\end{array}$ & $\begin{array}{l}\text { Global; Ecuador, El } \\
\text { Salvador, Guatemala, } \\
\text { Morocco, Nepal }\end{array}$ & $\begin{array}{l}\text { Soil and water resources; forests and } \\
\text { woodlands; biodiversity (both } \\
\text { "wild" and agrobiodiversity }\end{array}$ \\
\hline $\begin{array}{l}\text { Urbanization } \\
\text { including the growth } \\
\text { of periurban areas }\end{array}$ & $\begin{array}{l}\text { Influences of agglomeration in } \\
\text { industrial and service sectors }\end{array}$ & 1970-present & $\begin{array}{l}\text { Seto et al. 2010, } \\
\text { Thebo et al. } 2014, \\
\text { Seto and } \\
\text { Ramankutty } 2016\end{array}$ & $\begin{array}{l}\text { Global; Brazil, } \\
\text { China, Western } \\
\text { European countries, } \\
\text { India, USA }\end{array}$ & $\begin{array}{l}\text { Agri-food systems of cropping (e.g., } \\
\text { monoculture) and livestock (e.g., } \\
\text { confinement); periurban agriculture }\end{array}$ \\
\hline $\begin{array}{l}\text { Environmental and } \\
\text { agricultural } \\
\text { governance }\end{array}$ & $\begin{array}{l}\text { Expanded global institutional } \\
\text { and policy instruments (e.g., } \\
\text { conservation areas, REDD+, } \\
\text { PES) }\end{array}$ & 1995-present & $\begin{array}{l}\text { Zimmerer } 2006, \\
\text { Challies et al. } 2014, \\
\text { Liu et al. } 2015\end{array}$ & $\begin{array}{l}\text { Global; Brazil, } \\
\text { Burkina Faso, China, } \\
\text { Colombia, Lao PDR, } \\
\text { Thailand }\end{array}$ & $\begin{array}{l}\text { Conservation and protected areas } \\
\text { with human populations and use of } \\
\text { land and other resources }\end{array}$ \\
\hline $\begin{array}{l}\text { Direct investment } \\
\text { (contract farming); } \\
\text { Dispossession via } \\
\text { land, water, and } \\
\text { resource grabs }\end{array}$ & $\begin{array}{l}\text { National and international } \\
\text { agribusiness; capital limits in } \\
\text { smallholder SES }\end{array}$ & Late 1980 s- & $\begin{array}{l}\text { Freidberg } 2004, \\
\text { Friis et al. 2016b, } \\
\text { Friis and Nielsen } \\
\text { 2016, Schaffartzik } \\
\text { et al. } 2016\end{array}$ & $\begin{array}{l}\text { Burkina Faso, } \\
\text { Ghana, Kenya, } \\
\text { Indonesia, Lao PR, } \\
\text { Zambia }\end{array}$ & $\begin{array}{l}\text { Fruit, vegetable, and tree crop } \\
\text { systems, can be medium- or large- } \\
\text { scale plantation or smallholder }\end{array}$ \\
\hline
\end{tabular}

we identify a suite of factors as strengths, weaknesses, opportunities, and threats facing the sustainability of telecoupled smallholders.

The potential social-ecological resilience of smallholders is treated as relational, meaning it combines the internal characteristics of smallholders, e.g., gender and socioeconomic differences within and among households and resource users (Zimmerer et al. 2015) and their external environment (Darnhofer et al. 2016). This research focuses on how these combined internal and external factors function with respect to (i) the telecoupled global systems impacting smallholders; (ii) smallholder resource and land access and use; (iii) public and private institutions including markets and national-level governance; and (iv) local interactions among smallholders in their communities and landscapes. The conditions of these major factors is found to either enable or constrain potential sustainability.

These four elements are then used to construct the conceptual framework of smallholder telecoupling, which is intended to aid understanding and analysis of the potential sustainability of smallholder social-ecological systems. By explicitly integrating the linkages of smallholders, their resource and land use, national institutions and local interactions, this framework extends beyond the conventional telecoupling model. Moreover, it provides one of the first structured examples of "multiple telecouplings" (Liu et al. 2015) integrating both the dominant global "sending systems" and the various other public and private institutions that also play crucial roles in telecoupling. We address the value of understanding smallholder telecoupling in the penultimate section by demonstrating how this study and its framework contribute to sustainability opportunities and challenges in ways that are scientifically rigorous, conceptually robust, and policy relevant for multiple stakeholder groups. The conclusion highlights ways to move forward in research, policy, and management on the telecoupling of smallholder social-ecological systems.

\section{BACKGROUND: DATA OVERVIEW OF SMALLHOLDER TELECOUPLING AND CONCEPTUAL ORIENTATION OF RESEARCH}

Because research to date has utilized other frameworks, such as commodity chain analysis and globalization (Woods 2007, Challies 2008), or has focused telecoupling analysis on land and resource use that is significantly different than smallholder socialecological systems, this section's background information is synthesized from existing studies worldwide (Table 1). These studies are used to identify the predominant telecoupling of smallholders via global receiving systems and networked linkages (Table 1, first column). The key linkages of major global "receiving systems," such as expanding urbanization, can also be illustrated demographically by estimating the rapidly expanding numbers of smallholders located in and near periurban areas (Fig. 1). This smallholder telecoupling is reflected in expanded periurban agriculture worldwide (Berdigué and Fuentealba 2011, Thebo et al. 2014) and, in certain cases, high biodiversity in the smallholder agri-food systems of periurban gardens and fields (Lerner and Eakin 2011, Zimmerer 2014, 2018, Zimmerer et al. 2015).

Expanded migration illustrates other key linkages of telecoupled smallholders via their expanding integration into global labor markets (Table 1). Expanded global migration (Fig. 2), estimated to exceed 5 million persons annually, is crucial in understanding smallholder telecoupling because their households make up an important component within these estimates. This smallholder telecoupling is associated with human migration for employment and as refugees (de Haas 2006, Castles et al. 2013). Migrationrelated international remittance transfers now account for $30-50 \%$ of the foreign exchange earnings of several countries in Asia, e.g., Bangladesh and Nepal, Africa, e.g., Morocco and Tunisia, and Latin America, e.g., El Salvador and Bolivia. Global data of the World Bank indicate that the migration remittances received in sending countries are nearly four times larger than the total Official Development Aid (US\$601 billion vs. US\$160 billion, respectively; 
World Bank 2017a,b). In short, the rapid increase of global migration (Fig. 2) leads the global aggregate of migration remittances representing microlevel flows to surpass severalfold the total aid flows that are often more visible and widely publicized.

Fig. 2. Estimated increase of global net migration from Asia, Africa, and Latin America, 1998 to 2017. These are estimates of annual global migration flows from nonreceiver areas, drawn from the U.S. Central Intelligence Agency (CIA) World Factbook (CIA 2014, 2017). Net migration flows were summed among nonreceiver countries that are the source of global emigration flows (i.e., all countries excluding Canada, the United States, Europe, Australia, New Zealand, the Gulf States, Saudi Arabia, Japan, and Singapore). The plotted line represents the linear regression trend of annual data, which is significantly positive at $\mathrm{p}<0.0001$ using Kendall's tau for nonparametric correlation.

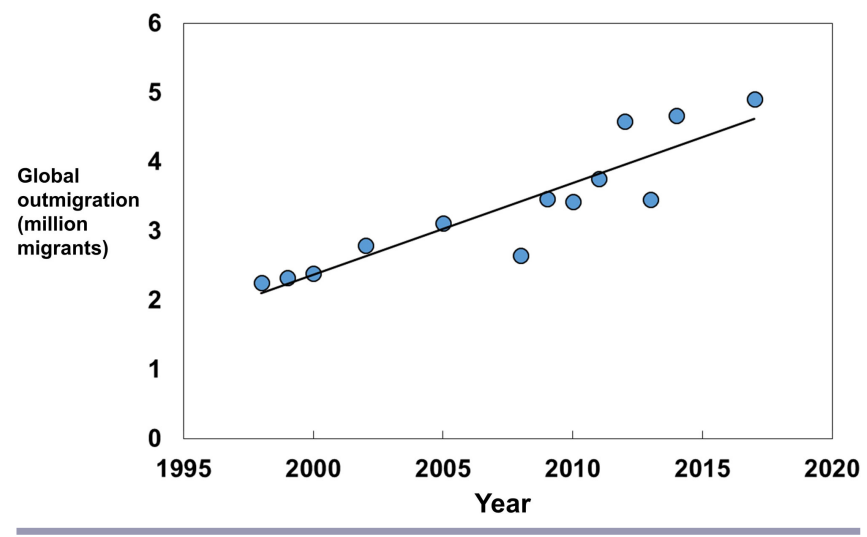

Although migration is often directed to rapidly growing cities, many migrants maintain connections to the smallholder households and communities that function as telecoupled "sending systems." In general smallholder livelihoods are based on diversification involving increased non- and off-farm employed (Reardon 1997, Ellis 1998, Carr 2009, Castles et al. 2013, Zimmerer and Vanek 2016). Representative of new rurality, smallholder migration also flows to in-country resource frontiers. Expanded migration therefore connects the telecoupled resource and land use of smallholders to distant urban, periurban, and rural areas.

Following earlier insights into the globalization-driven environmental interactions of migration (Carr 2009, Gray 2009), many migrants are also now recognized as continuing to impact smallholder environments remotely through their continued ties (Castles et al. 2013). Telecoupled linkages, such as monetary remittances, information exchange, and shared decision making, connect migrants to the smallholder agroecosystems of their households (and individuals therein), communities, and social networks. This international migration drives changes in smallholder environments that are either beneficial or destructive with regard to sustainability (Gray 2009). Synthesis research has evaluated the conditions influencing the divergent sustainability outcomes of smallholder migration, such as the roles of resource access, economic rationales, and cultural valuation (Zimmerer and Vanek 2016).
Smallholder telecoupling is also evident in global forest transitions that incorporate smallholder populations involved in both secondary forest regrowth and forest clearing (Rudel et al. 2005). Effects of the global trade in forest products (Meyfroidt et al. 2013) and livestock are combined with the effects of smallholder migration, urbanization, and environmental governance. The spectrum of secondary forest transitions spans both rural depopulation (Aide and Grau 2004) and the sizeable smallholder populations of Asia, Africa, and parts of Latin America (Carr 2009). Smallholders are also impacted through long-distance commodity flows (Adger et al. 2009) and environmental governance mechanisms that are exerting impacts on global forest ecosystems, including both degradation and conservation (Rudel et al. 2005, Meyfroidt et al. 2013).

Additional factors in smallholder telecoupling include the mediating dynamics of public and private institutions that both drive at-a-distance linkages such as the retail and supermarket revolutions (Reardon et al. 2003, 2014, Reardon and Hopkins 2006) and that enable the connection of receiving systems and sending systems, e.g., via telecommunications ranging from cell phone to mobile money capacities, social media, and nongovernmental organizations (Aker and Mbiti 2010, Suri et al. 2012) whose roles are addressed further below, as well as "green" investments in nature conservation and land restoration by private actors, and sustainability standards that are imposed on producers via the global supply chains of transnational companies (Meyfroidt et al. 2013). The combined conceptual orientation and data analysis provided here furnish important background needed to integrate the understanding of smallholder telecoupling and social-ecological systems that can be gained from the analysis of case studies and model building below.

\section{RESULTS: SYNTHESIS OF CASE STUDIES OF POTENTIAL SUSTAINABILITY}

The case studies were chosen to provide insights into sustainability and sustainable development, as well as the limits thereof, while recognizing that similar evaluations are still needed in other examples of smallholder telecoupling such as the global retail and supermarket revolutions (Reardon et al. 2003, Reardon and Hopkins 2006). Moreover, the case studies reflect the recent research experience of the authors along with the selective use of related works. In addition, they were chosen to encompass both the analysis of telecoupling linkages (defined to include distant drivers) and local social-ecological systems.

These case studies are social-ecological systems combining smallscale agroecosystems with significant international labor migration (high-biodiversity ecosystems of Andean maize varieties in Bolivia), eco-certified crops and agroforestry systems (coffee in Colombia), organic-certified smallholder dairy production (USA), and high-value niche products (argan oil in Morocco). Visualization in Figure 3 is useful in illustrating the variation and range of these four case studies. As an aid to understanding and synthesizing the specific findings, the defining characteristics of the case studies are distilled (Table 2) and the specific instances of both sustainability opportunities and limits are identified (Fig. 4). 
Table 2. Attributes of the case studies of telecoupled smallholder social-ecological systems (details in each of the case studies)

\begin{tabular}{|c|c|c|c|c|}
\hline Social-Ecological System & $\begin{array}{l}\text { Predominant } \\
\text { Telecoupling }\end{array}$ & $\begin{array}{l}\text { Sustainability Opportunities and } \\
\text { Limits To Date }\end{array}$ & $\begin{array}{l}\text { Local Spatial and Social } \\
\text { Interactions }\end{array}$ & $\begin{array}{l}\text { Roles of National } \\
\text { Institutions }\end{array}$ \\
\hline $\begin{array}{l}\text { Agrobiodiversity of Andean } \\
\text { Maize (Cochabamba, } \\
\text { Bolivia) }\end{array}$ & $\begin{array}{l}\text { International } \\
\text { migration (global } \\
\text { labor market) and } \\
\text { urbanization }\end{array}$ & $\begin{array}{l}\text { All principal subspecific maize } \\
\text { landraces conserved during recent } \\
\text { migration }\end{array}$ & $\begin{array}{l}\text { Significant field clustering } \\
(\mathrm{p}<0.01) \text { strengthens } \\
\text { resilience }\end{array}$ & $\begin{array}{l}\text { National-level resource tenure } \\
\text { governance and product } \\
\text { markets; community } \\
\text { organizations }\end{array}$ \\
\hline $\begin{array}{l}\text { Coffee Agroforests (western } \\
\text { Colombia) }\end{array}$ & $\begin{array}{l}\text { Global eco- } \\
\text { certification }\end{array}$ & $\begin{array}{l}\text { Certified coffee farms more tree } \\
\text { cover }(p=0.001) ; 9 \text { tree spp/ha vs. } 6 \\
(p<0.001)\end{array}$ & $\begin{array}{l}>50 \% \text { certified farms } \\
\text { motivated by stronger ties } \\
\text { with neighbors }\end{array}$ & $\begin{array}{l}\text { Crucial role of national-level } \\
\text { Federation of Coffee } \\
\text { Growers }\end{array}$ \\
\hline $\begin{array}{l}\text { Organic dairy (Upper } \\
\text { Midwest and northeastern } \\
\text { United States) }\end{array}$ & $\begin{array}{l}\text { International } \\
\text { technology } \\
\text { development and } \\
\text { product markets }\end{array}$ & $\begin{array}{l}\text { Increased floristic diversity, soil } \\
\text { microbial, and faunal community }\end{array}$ & $\begin{array}{l}\text { Significant spatial spillover } \\
\text { causing clusters of organic } \\
\text { dairy }(\mathrm{p}<0.01)\end{array}$ & $\begin{array}{l}\text { USDA organic food } \\
\text { governance; organic farmer } \\
\text { organizations }\end{array}$ \\
\hline $\begin{array}{l}\text { Argan Woodland (Atlas } \\
\text { Mountains, Morocco) }\end{array}$ & $\begin{array}{l}\text { Global trade in } \\
\text { argan oil }\end{array}$ & $\begin{array}{l}\text { Forest density has declined } 44.5 \% \\
\text { (1970-2007) due to increasing } \\
\text { aridity and fuelwood extraction }\end{array}$ & $\begin{array}{l}\text { Argan woodlands impact } \\
\text { the water supply for } \\
\text { cultivated fields }\end{array}$ & $\begin{array}{l}\text { Argan woodlands owned and } \\
\text { managed by government }\end{array}$ \\
\hline
\end{tabular}

Fig. 3. Agroecosystems and landscapes amid expanded smallholder telecoupling (clockwise from upper-left: cultivation of Andean maize among migrant households of telecoupled smallholders in Cochabamba, Bolivia; argan as high-value land use product in Morocco; coffee as eco-certified crop in agroforestry system in Santander, Colombia; small-scale organic dairy producers in Wisconsin, U.S. (photocredits: Karl Zimmerer, Ximena Rueda, Yann le Polain de Waroux, Karl Zimmerer)

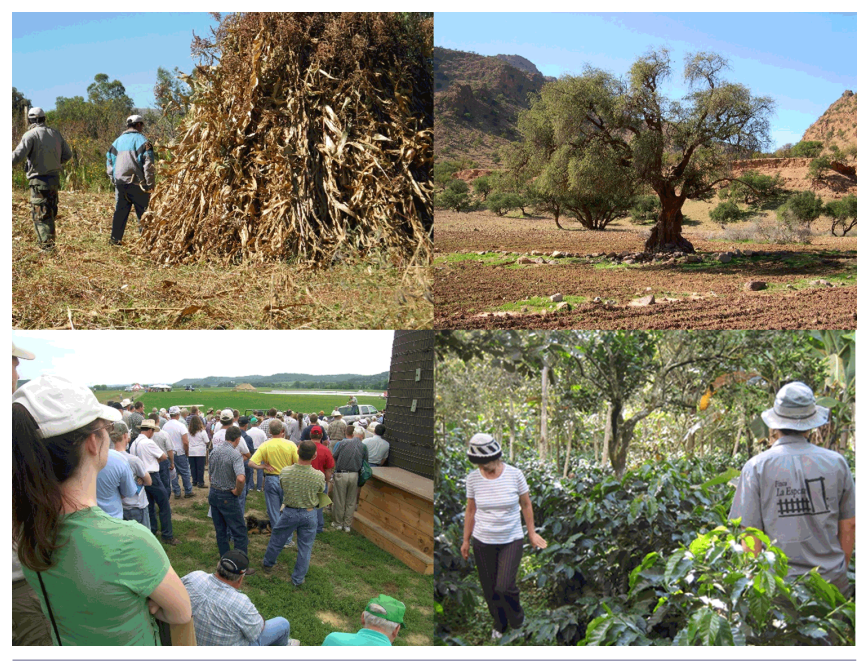

International migration and high-agrobiodiversity Andean maize Expanding migration at the global scale is linked to smallholder environmental interactions (Zimmerer and Vanek 2016). Recent research in Bolivia illustrates this smallholder telecoupling. Since the 1990s these smallholders have expanded migration to "receiving systems" of inexpensive labor markets that are international (principally Argentina, the United States, and Spain) and national within Bolivia (principally the cities of La Paz, Cochabamba, and Santa Cruz) as well as in-country resource frontiers. Most migrants utilize the mobile money technologies of private business institutions to transmit remittances to their household members engaged in smallholder farming. These smallholder households and communities thus serve as "sending systems" in telecoupled labor markets demonstrating the characteristics identified the preceding section.

Findings show that smallholders with members that migrate, i.e., telecoupled smallholders, have disproportionately continued to produce the local varieties or landraces of Andean maize (Fig. 3; Zimmerer 2013, 2014). Their continued growing and consumption in Bolivia is responsible for the global hotspot conserving 10 principal landraces and as much as $3-4 \%$ of the subspecific-level taxonomic diversity of maize in tropical Latin America within areas as small as $30 \mathrm{~km}^{2}$, i.e., less than $0.00001 \%$ of the land area of tropical Latin America (Zimmerer 2013). These estimates suggest the potential sustainability of high maize biodiversity (agrobiodiversity) used by telecoupled smallholders, while future research at the population and genetic levels is also needed. This potential sustainability is enabled by the combination of migration remittances, diversified livelihoods, and part-time farming (Fig. 4), a clear example of smallholder telecoupling, as well as by their local access to adequate land, water, and labor resources. Combined with the economic and cultural valuation of Andean maize, these factors provide important support for the potential sustainability and sustainable development of telecoupled smallholder agroecosystems (Zimmerer 2014). Vibrant regional seed systems are also important, though not yet subject to systematic analysis in the specific social-ecological systems of these telecoupled smallholders.

Expanded telecoupling of smallholder agrobiodiversity in Bolivia, as well as the other Andean countries (Gray 2009, Zimmerer and Vanek 2016) interacts with the influences of public and private institutions at global and national levels (Table 2). Tenure rights enforced through national and local organizations are often sufficient to enable adequate land and water access (Fig. 4). In addition, the existence of on-farm agrobiodiversity management (OFAM) using citizen science among socially wellorganized farm communities and women's groups, for example, attracts the participation and support of both global and national institutions (Nilsen et al. 2015) targeting adaptive management in smallholder landscapes (Jackson et al. 2010; Table 2). 
Fig. 4. Predominant characteristics of the telecoupling of smallholder social-ecological systems with potential contributions to sustainability.

\section{Smallholder households/local communities}

\section{Telecoupled linkages}

\section{Opportunities}

- Production of niche commodity products with special branding and price premium to producer; infrastructure support (e.g., fair trade coffee brands)

High capacity to engage in livelihood diversification and part-time farming with off- and nonfarm employment

(e.g., migration); flexible labor allocation

- Local knowledge of production, resources, and uses of market products and self-provisioning food; capacity to use varied production environments ("agrobiodiversity")

- Ability to manage multispecies crop systems and to combine varied livestock and cropping systems ("agrobiodiversity") across multiple land use units

- Spatial coordination of small units of agriculture and land owing to management of irrigation, pest control, soil management, and labor

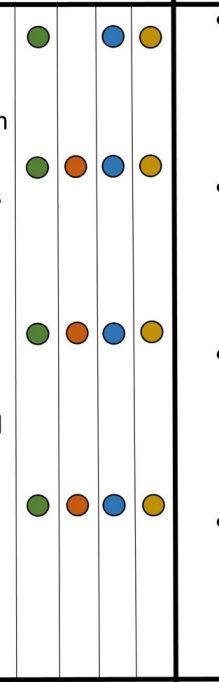

\section{Weaknesses}

- Low access and marginal production quality of land and water resources; limited capital resources; constrained credit access

- Vulnerability to environmental (e.g., climate change) and socioeconomic (e.g., price volatility) shocks

- Small field sizes and economic units constraining production scale and use of certain technologies (e.g., improved irrigation)

- Social disempowerment; low levels of technical and nontechnical education; vulnerability to local resource grabs; limited access to institutions

- Precarity and low resilience to factors of environmental, sociocultural, and political systems
- Support of national-level policies and institutions (e.g., producer organizations, state agencies supporting land and water tenure rights)

- Support of NGOs, social indigenous movements for land and water rights), and international agencies

- Ability to utilize family and community social networks on-farm and in non- and off-farm labor markets (e.g., migrant labor) movements (e.g., small farmer and

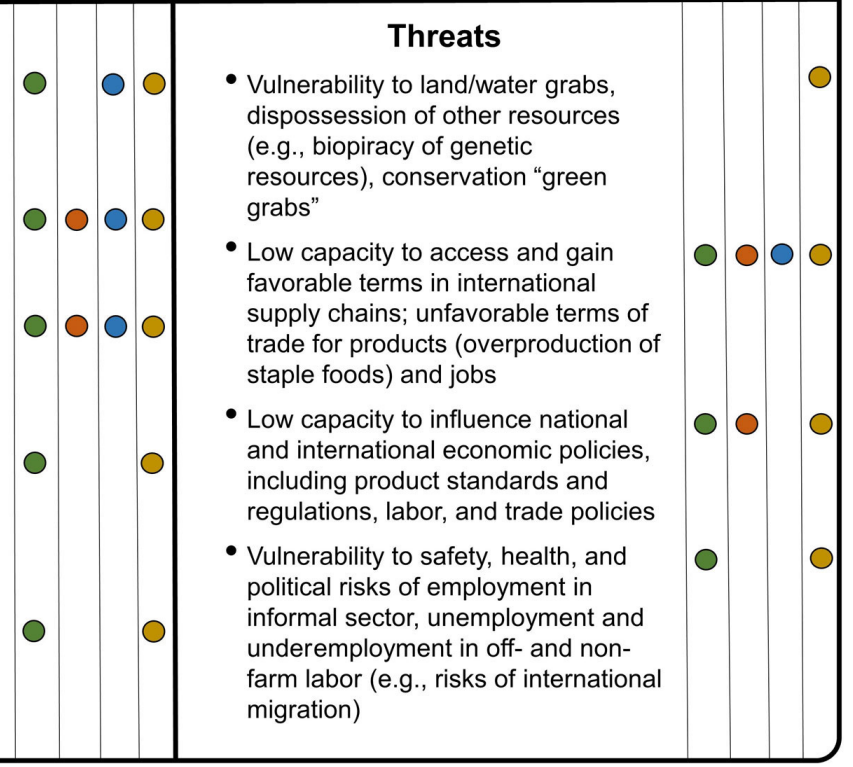

\section{Legend}

Color coding represents applicability of case studies to each element. The principal telecoupled factor is the dominant commodity, except where noted otherwise in the legend.
High-Agrobiodiversity Maize and International Migration

Coffee Agroforests Organic Dairy $\bigcirc$ Argan Oil
Local spatial spillovers involving resource coordination, such as irrigation, labor-sharing, and pest management among neighboring smallholders, are also important among the telecoupled smallholders in Bolivia that grow highagrobiodiversity Andean maize. Comprising positive spatial externalities, these effects lower production costs and result in the spatial clustering of these maize fields within the local farm landscape (Zimmerer and Rojas Vaca 2016). Conversely, the weakness of these factors can undermine agrobiodiversity. In related cases, such as GM crops bordering organic agriculture that requires non-GM production, the local spatial spillovers result in dispersal effects (rather than clustering) representing negative spatial externalities (Parker and Munroe 2007). 


\section{Telecoupled markets and governances in certified coffee-based agroforestry}

Driven by increasing global demand for high-quality beverage commodities, and long-term trends including declining prices, many associations of smallholder producers worldwide have adopted value-added strategies designed to increase profit. One strategy features third-party certifiers, such as Rainforest Alliance, Equal Exchange and Fair Trade, and numerous others, that promote specific ecological and social goals. These certifiers support smallholder coffee-growing and thereby the associated agroforestry landscapes (Fig. 3; Rueda and Lambin 2013a). In this case, telecoupling transmits to smallholder landscapes the preferences of distant consumers willing to pay a price premium (Table 2, Fig. 4).

Coffee eco-certification in Colombia shows the powerful influence of global market signals and a very high level of responsiveness in the decisions of telecoupled smallholders (Fig. 4; Rueda et al. 2015). The regions of Colombia most likely to grow differentiated coffees have experienced the greatest production increase. These linkages have exerted a powerful influence on land use decisions among the individual households of telecoupled smallholders. Coffee-growing smallholders have improved their resource management, making use of technologies to run their operation more efficiently, and are also more engaged in conserving key ecosystem services - protection of watersheds and soil fertility - and biodiversity. These changes in land use have significant impacts on tree cover on certified farms detectable through remote sensing (Rueda et al. 2015).

The success of Rainforest Alliance coffee certification in Colombia can be traced to support of the Colombian Coffee Growers' Federation (Table 2, Fig. 4). It helped create supply chains for differentiated markets, improved coordination between actors in the supply chain, deepened its relationship with clients in export markets, transferred a substantial part of price premium to farmers, leveled access to certification for small and large holders, gave access to low-cost technologies, and channeled resources to help poor farmers upgrade equipment (Rueda and Lambin 2013a). At the scale of local communities, coffee certification has generated positive spillover effects on adjacent farms and communities through emulation of practices (Rueda and Lambin 2013b). Benefits of certification extended beyond economic rewards. Farmers have gained access to new knowledge and information, e.g., technologies from research centers have better reached certified farmers via extension agents working for the coffee cooperatives and the Colombian national government. Certified producers became better connected to their peers, e.g., they organized monthly meetings to share experiences, exchange practices, and gain access to resources. Children of certified farmers were better educated and played a greater role in farming decisions (Rueda and Lambin 2013b).

\section{Telecoupling and organic dairy farming}

Organic dairy producers in the U.S. are an example of telecoupling owing to connections to distant product markets, price signals, and technology change (Table 2, Fig. 4). Sizeable numbers of smallholder farmers in the Upper Midwest, for example, have chosen to produce for national organic dairy markets whose significant price premiums operate at a distance. Smallholder organic dairy is especially common in areas such as the environmentally varied Driftless Area of western Wisconsin (agrodiversity sensu Brookfield 2001; Fig. 4). Commodity price premiums have been influential in the expansion of organic dairy in the U.S, including the Upper Midwest. A significant number of organic dairy operations in the Driftless Area are smallholders that have less than 20 ha of farmland and cow herds of $80-150$ head, significantly below the national mean of 500 (Lewis et al. 2011).

This smallholder organic dairy production illustrates "multiple telecouplings" (Liu et al. 2015). Capacity of the Upper Midwestern smallholders to supply organic milk to telecoupled distant national markets has depended also on the import of European technology known as ultrahigh temperature (UHT) processing. This technology extends the nonperishable shelf life of fresh milk to several months, thus interacting with the telecoupling of the niche commodity market and enabling the competitiveness of these smallholders. Smallholder dairy viability in this region has also depended on the successful CROPP Cooperative, the largest agricultural cooperative in the U.S. that effectively accesses distant markets and evidences extensive telecoupling (Fig. 4). In addition, the smallholder members rely extensively on telecoupling technologies as cell phones and social media to take advantage of CROPP services.

Ecological improvements of smallholder organic dairy farming arise through medium-input approaches that include rotational grazing and pasture management that are more sustainable than other techniques (Lewis et al. 2011). Specific agroecosystem benefits include greater resources for pollinators because of floristic diversity and increased density of beneficial arthropods in hedgerows as well as increased insect abundance in cowpats. Reductions in nitrogen $(\mathrm{N})$ pollution of waterways in organic dairy systems are traced to reduced off-farm $\mathrm{N}$ inputs and $\mathrm{N}$ farmgate balances (35\% lower) and dramatic reductions (>90\%) in the use of antibiotics for cows that reduce water pollution.

In addition, local spatial interactions and spillover effects associated with the conversion to organic dairy play a key role because this decision making depends on information exchange in local farmer and social organizations as well as informal networks (Lewis et al. 2008, 2011). Local education opportunities are also important, such as local civic and farmer organizations that support organic dairy field days (Fig. 3). National policies and institutions are similarly vital to the success of smallholder organic dairy in the Upper Midwest. Regulations of the U.S. Department of Agriculture (USDA), as well as national organic certification standards, are generally compatible, though smallholder organic dairy producers consider national policies and institutions less than ideal and subject to change amid political shifts.

\section{Telecoupled niche commodities: argan oil and smallholder woodlands}

Many smallholder landscapes are being integrated into global markets through high-value products such as argan oil, acai, quinoa, and shea butter that are sought by global consumers. A number of these niche commodities share attributes of endemism, scarcity, and marketing narratives of uniqueness. This commercialization connects some of the planet's wealthiest consumers with often poor smallholders. The rationales for this production among telecoupled smallholders include income 
Fig. 5. The conceptual framework of multilevel smallholder telecoupling.

\section{Basic Framework}

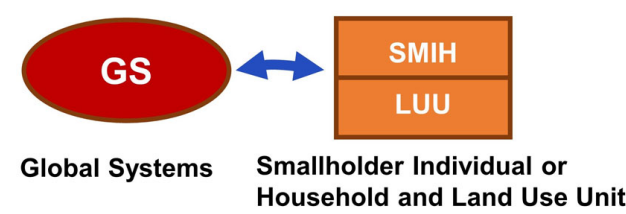

\section{Legend}

\begin{tabular}{|c|c|}
\hline & $\begin{array}{l}\text { Telecoupling among sendi } \\
\text { and receiving systems }\end{array}$ \\
\hline & $\begin{array}{l}\text { Interactions among } \\
\text { smallholders and national } \\
\text { institutions }\end{array}$ \\
\hline & $\begin{array}{l}\text { Interactions among global } \\
\text { and national systems }\end{array}$ \\
\hline & $\begin{array}{l}\text { Local interactions among } \\
\text { smallholders }\end{array}$ \\
\hline SMIH & $\begin{array}{l}\text { Smallholder Individual or } \\
\text { Household }\end{array}$ \\
\hline LUU & Land Use Unit \\
\hline
\end{tabular}

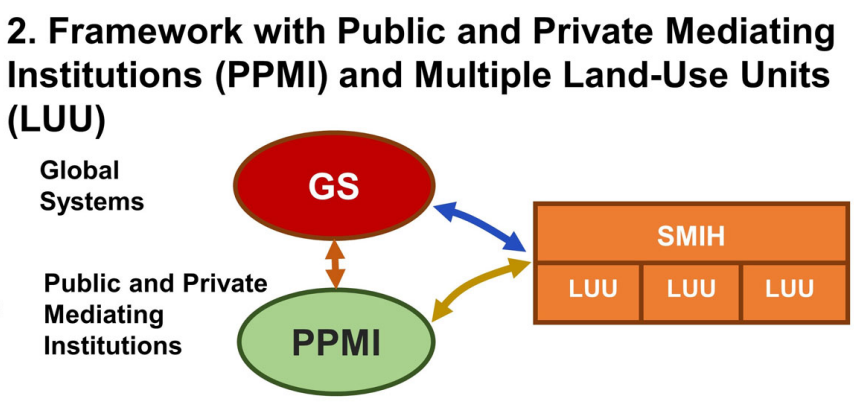

\section{Framework with Spatial Interactions (spillovers)}

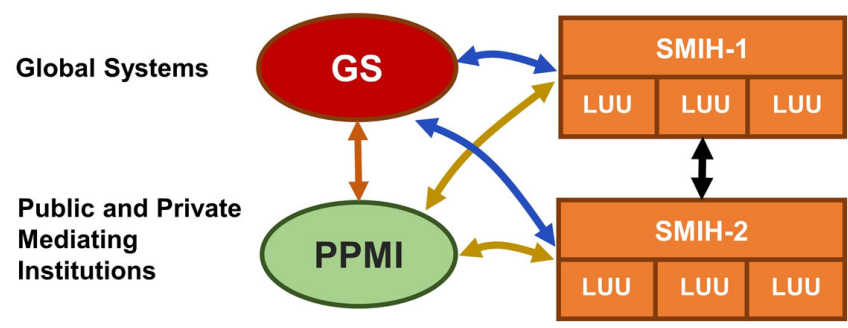

growth and diversification though not necessarily with significant benefit. For example, the commercialization of argan oil extracted from this savanna tree in Morocco (Table 2, Fig. 3), which is sold globally for prices over US $\$ 400$ per liter, has delivered little benefit in marginal regions (le Polain de Waroux and Lambin 2013), while this income has been significant for some smallholders in more centrally located communities (Lybbert et al. 2004). At the same time, nonfarm activities and remittances have represented a larger source of income for most Moroccan smallholders than income from argan oil. Meanwhile the density of forests, which are dominated by argan trees, was reduced by $44.5 \%$ in some regions owing to increased aridity and fuelwood extraction (le Polain de Waroux and Lambin 2012). Overall the telecoupling of argan landscapes have incurred few positive, and sometimes negative environmental and social impacts (Table 2, Fig. 4).

Local communities were able to capture limited benefits from telecoupling through the marketing of argan oil because of their lack of social networks spanning the value chain and the dominance of the Moroccan state in forest management (le Polain de Waroux and Lambin 2013). The recent adoption of Fair Trade certification and protection of argan oil under a Geographical Indication reflect an attempt at influencing the value chain in order to increase the value to local producers. Women-led cooperatives for the transformation of argan nuts were created with the support of the European Union and the Moroccan "Agence de Développement Social", among others. The creation of cooperatives has altered gender relationships, bolstering the social recognition of women. It creates an economic and social opportunity, particularly for socially disadvantaged women. The cooperatives have promoted education, which has contributed to higher school enrollment among girls (Lybbert et al. 2011). The boom has also prompted new land tenure claims and contestations, and intensified competition over resource access (le Polain de Waroux and Lambin 2013).

\section{EXTENDED RESULTS SYNTHESIS: CONCEPTUAL FRAMEWORK FOR THE TELECOUPLING OF SMALLHOLDER SOCIAL-ECOLOGICAL SYSTEMS}

Based on the above, we can construct a conceptual framework of smallholder telecoupling (Fig. 5). This framework first designates global systems (GS) that are operating worldwide (Panel 1 in Fig. 5). These systems vary from globalizing markets (e.g., labor, product, and finance markets), urbanization, environmental governance, and technological innovation to globalizing ideas and awareness. Some of these global systems are connected as sending and/or receiving systems to individual smallholders and their households ( $\mathrm{SHH})$ combined with its units of land use (LUU). The conceptual framework being constructed here uses the insights of political ecology and livelihoods research.

This conceptual framework utilizes feminist political ecology (FPE) to highlight the significant variation within and among smallholder households (Zimmerer 2004, Radel et al. 2010, Radel and Coppock 2013, Zimmerer et al. 2015, Moseley 2016, Vadjunec et al. 2016, Zimmerer and Vanek 2016). It recognizes the household per se rarely functions as a socially cohesive unit, though it plays a major role in smallholder responses to telecoupling. The so-called partial unity, or the linkage, of the production and consumption activities is crucial as a feedback loop, for example, in the conservation and continued foodgrowing and use of high-agrobiodiversity Andean maize in Bolivia, as described above. 
Table 3. Multilevel elements of the framework of telecoupled smallholder social-ecological systems (SES; see also Fig. 5)

\begin{tabular}{|c|c|c|c|c|}
\hline $\begin{array}{l}\text { Panel and Elements in } \\
\text { Figure } 5\end{array}$ & Global Systems & Sending System(s) & $\begin{array}{l}\text { Public and Private } \\
\text { Mediating Institutions } \\
\text { (PPMI) }\end{array}$ & Local Spillover System(s) \\
\hline Level 1. Basic framework & $\begin{array}{l}\text { Global system driving telecoupled } \\
\text { linkages (see examples in Table 1) }\end{array}$ & $\begin{array}{l}\text { Smallholder individuals and } \\
\text { households (SMIH) and } \\
\text { land use unit (LUU) }\end{array}$ & $\begin{array}{l}\text { Not contained in the Level } \\
1 \text { framework }\end{array}$ & $\begin{array}{l}\text { Not contained in the Level } \\
1 \text { framework }\end{array}$ \\
\hline $\begin{array}{l}\text { Level 2. Expanded with } \\
\text { PPMI and multiple land } \\
\text { use units (LUU) }\end{array}$ & $\begin{array}{l}\text { Expands on Level } 1 \text { with the } \\
\text { addition of PPMI (e.g., cell phones, } \\
\text { mobile money, national-scale } \\
\text { agencies; see text) operating across } \\
\text { national, global, and local scales }\end{array}$ & $\begin{array}{l}\text { The addition of multiple } \\
\text { land use units that are } \\
\text { common to many } \\
\text { smallholder SES }\end{array}$ & $\begin{array}{l}\text { Principal elements in Level } \\
2 \text { (note: this level is not } \\
\text { contained in existing } \\
\text { telecoupling frameworks) }\end{array}$ & $\begin{array}{l}\text { Not contained in the Level } \\
2 \text { framework }\end{array}$ \\
\hline $\begin{array}{l}\text { Level 3. Further } \\
\text { expanded framework } \\
\text { with multiple } \\
\text { smallholders and } \\
\text { spillovers } \\
\text { (Level 3) }\end{array}$ & $\begin{array}{l}\text { Expands on Level 2, with the } \\
\text { addition of multiple smallholder } \\
\text { individuals and households } \\
\text { interacting globally }\end{array}$ & $\begin{array}{l}\text { The addition of multiple } \\
\text { local smallholders and } \\
\text { spatial spillovers }\end{array}$ & $\begin{array}{l}\text { PPMI integral to spillover } \\
\text { systems (e.g., cell phones } \\
\text { in coordinating resource } \\
\text { use; see text) }\end{array}$ & $\begin{array}{l}\text { Principal element in Level } 3 \\
\text { because common in } \\
\text { telecoupled smallholder } \\
\text { SES }\end{array}$ \\
\hline
\end{tabular}

Beyond the linkages of global receiving systems and often distant smallholders, the four case studies highlight the importance of both private and public institutions operating across the range of global, national, and local scales that impact smallholder (Fig. 5, Table 3). Private institutions, including businesses, providing such capacities as cell phone connectivity and mobile money help to enable the linkages of telecoupled smallholders in each of the case studies. These findings are consistent with the robust economic and development literatures on the expanding roles of private institutions among smallholders in such important regions as Africa, Asia, and Latin America (Aker and Mbiti 2010, Suri et al. 2012).

Similarly, the four case studies highlight the role of public institutions that often operate nationally such as national level institutions for agriculture and resource governance as well as commodity programs (Table 3 ). These national-level institutions exert influence on smallholder telecoupling involving such issues as development in addition to global environmental change and governance (Kissinger et al. 2011). The case studies provide ample evidence of their importance, such as the national land tenure laws needed for international migration with continued smallholder land use in Bolivia, the national coffee-growers federation in Colombia, and the roles of U.S. Department of Agriculture organic standards and national certification guidelines for organic dairy. It is precisely the lack of national support for smallholders in argan woodlands and the Moroccan government's concentration of governance power through the national forestry administration that conspicuously undermine sustainability.

The conceptual model is designed to account for these influences by designating Public and Private Mediating Institutions (PPMI, Panel 2 in Fig. 5). These mediating institutions link telecoupled smallholders to global systems through the diffusion of new technologies, sustainability values, and production standards, and through global governance and market mechanisms. In addition, the case studies recommend expanding the model to account for the role of multiple, diverse units of land use characteristically managed by the individual households within smallholder landscapes (Panel 2 in Fig. 5). The small-size and environmental heterogeneity of these multiple units of land use can foster the capacity of versatile and varied responses of telecoupled smallholders.

Finally, the spillover effects created through multiscale spatial interactions are a fundamental component of the telecoupling of smallholder social-ecological systems. In addition to the emphasis on spillovers at global and national scales (Liu et al. 2013, 2015), the framework developed here defines spillovers as also potentially occurring among adjacent units of land use (Panel 3 of Fig. 5; Table 4). Smallholder systems of land use tend to contain high edge-area ratios of fields that increase the likelihood of influential spatial interactions and hence these types of spillover effects with neighboring and nearby units. These spillover effects can constitute either positive or negative spatial externalities. For example, between-field coordination of smallholder livestock management determines nutrient gradients and capacities for smallholder intensification (Giller et al. 2011). Such benefits can cascade and scale-up via local spatial spillovers, as exemplified by the adoption of organic agriculture and the viability of highagrobiodiversity maize (Table 4). More generally, the telecoupling of smallholder social-ecological systems propels spillover effects onto adjacent and nearby units of land use.

The spillover processes among smallholders can potentially be targeted as effective, scalable sustainability incentives (Table 4; Zimmerer and Rojas Vaca 2016). For example, policy incentives can leverage sustainability-enhancing positive spatial spillovers in order to diffuse desirable outcomes at lowered costs (Lewis et al. 2008; on spatial externalities and implications for the sustainability of land use see also Parker and Munroe 2007, Munroe et al. 2014). Taken as a whole the new conceptual framework comprises a multitier design consisting of three levels (Panel 5, Table 3). As explained in Table 3, it expands the basic version of the telecoupling framework (Level 1) to incorporate the importance of various private and public mediating institutions at the global and national scales (PPMI, Level 2) and the local interactions that occur as spatial spillover effects among smallholder social-ecological systems (Level 3). This conceptual framework involves the nested scales of the global-national-local sequence only partially because the PPMI operate across multiple scales. 
Table 4. Systematic description of local spillovers in telecoupled smallholder social-ecological systems (SES).

\begin{tabular}{|c|c|c|c|c|}
\hline Social-Ecological System & Location & $\begin{array}{l}\text { Local Externality and the Potential of } \\
\text { Enhanced Sustainability }\end{array}$ & Spatial Pattern of Spillover & References \\
\hline $\begin{array}{l}\text { Agrobiodiversity of } \\
\text { Andean maize }\end{array}$ & $\begin{array}{l}\text { Cochabamba, } \\
\text { Bolivia }\end{array}$ & $\begin{array}{l}\text { Coordination among smallholder } \\
\text { households with respect to the use of } \\
\text { irrigation, equipment, and pest control }\end{array}$ & $\begin{array}{l}\text { Clustering of fields with the } \\
\text { same crop within the local } \\
\text { landscape }\end{array}$ & $\begin{array}{l}\text { This study (also } \\
\text { Lewis et al. 2008, } \\
\text { Zimmerer and Rojas } \\
\text { 2016) }\end{array}$ \\
\hline $\begin{array}{l}\text { Eco-certified coffee } \\
\text { cultivation }\end{array}$ & Santander, Colombia & $\begin{array}{l}\text { Emulation of good practices between } \\
\text { neighboring farmers, monthly social } \\
\text { activities bringing together certified farmers }\end{array}$ & & $\begin{array}{l}\text { This study (also } \\
\text { Rueda and Lambin } \\
2013 a, b \text { ) }\end{array}$ \\
\hline Organic dairy & $\begin{array}{l}\text { Upper Midwest, USA } \\
\text { (Driftless Area, } \\
\text { Wisconsin) }\end{array}$ & $\begin{array}{l}\text { Coordination among organic dairy farmers, } \\
\text { with respect to practical information and } \\
\text { knowledge needed for organic certification } \\
\text { and farm management }\end{array}$ & $\begin{array}{l}\text { Clustering of organic- } \\
\text { certified dairy farms within } \\
\text { the local landscape }\end{array}$ & $\begin{array}{l}\text { This study (also } \\
\text { Lewis et al. 2008, } \\
\text { 2011) }\end{array}$ \\
\hline Organic vegetable-growing & $\begin{array}{l}\text { La Paz, Honduras } \\
\text { (southwest Honduras) }\end{array}$ & $\begin{array}{l}\text { Availability of information in the } \\
\text { smallholders' neighborhood and social } \\
\text { conformity concerns }\end{array}$ & $\begin{array}{l}\text { Increased organic growing } \\
(1.5 \mathrm{~km} \text { of main area })\end{array}$ & $\begin{array}{l}\text { Wollni and } \\
\text { Andersson } 2014\end{array}$ \\
\hline
\end{tabular}

\section{DISCUSSION: SUSTAINABILITY OPPORTUNITIES AND CHALLENGES IN SMALLHOLDER TELECOUPLING}

Notwithstanding tremendous variation with the category of smallholders (Zimmerer et al. 2015, Zimmerer and Carney 2018), their livelihoods and landscapes are mainly distinguished by extreme precariousness that is conspicuously un-Romantic (Table 5 , row 1). Similarly the large numbers of smallholders and their integration with market forces indicate nonteleological outcomes contrary to claims of prior or impending elimination (Table 5, rows 2-4). In addition, the mixed social-ecological outcomes of smallholder telecoupling provide further grounds for rejecting priori assumptions of their inherent social-ecological value (ecologically noble savage myth) or threat (eco-villain myth; Table 5 , row 5). Indeed it is often such beliefs, frequently held as unstated assumptions, that tend to plague and polarize scientific, policy, and public understandings of smallholders. By contrast, this research is focused on advancing rigorous studies of the sustainability of smallholder social-ecological systems, including agroecosystems, to the domains of practical knowledge, policy, and action (Turner 1997, Altieri et al. 2015, Clark et al. 2016)

One principal mechanism for expanded smallholder telecoupling is specialized commodity production for niche markets. Growing preferences of global consumers for niche-type products ideally transfers price benefits to smallholders, though major challenges are faced regarding whether such transfers can become reality (Dragusanu et al. 2014). Global supply chains of commodities such as coffee, cacao, and palm oil are exerting a major impact on the land use of smallholders worldwide, though with the socially and geographically uneven variation of costs and benefits (Mutersbaugh 2006). In some cases smallholders can potentially obtain gains by becoming core members of a differentiating production sector that is responding quickly to global market opportunities, e.g., eco- and fair trade-certified Colombian coffee, or by controlling endemic resources on smallholder lands, e.g., argan oil. The participation of smallholders in these telecoupled markets is often crosscut by the impact of global environmental governance mechanisms, such as UNFCC REDD, Payment for Environmental Service programs, and commodity roundtables. Additional telecoupling institutions are NGOs and international agencies.
The results of this research bridge global network analyses with landscape-level studies that include development-related processes (Bebbington and Batterbury 2001, see also Zimmerer 2006, Woods 2007, Challies 2008, Carr 2009). These research results also highlight the agency of smallholders in telecoupling that needs to be incorporated into scientific and systematic studies of the globalization of land use (Berdigué and Fuentealba 2011, Müller and Munroe 2014). This agency benefits from relatively accessible technologies and associated institutional innovations, such as cell phones, internet, and social media that enable communication of information on such factors as prices, labor, resources, and regulations (Zimmerer 2014). Moreover, their capacities for responsiveness and versatility take advantage of lower investment levels and more labor dependence than large landholders, along with growing technological savvy and awareness of extra-local information.

Spatial spillover interactions among smallholder producers can lead to the clustering of sustainability-enhancing land use (Table 4). It offers the important extension of the concept of "spillover" in telecoupling that otherwise refers to leakages and displacements in international flows of major global commodities (Liu et al. 2013, Meyfroidt et al. 2013). The approach of the present study is to formulate this concept as pertaining to patterns of adjacent land use and, in particular, those related to processes among smallholders and within their landscapes.

Telecoupled smallholders are frequently able to undertake multiple shifts in land use, thus diversifying production and farming systems in ways that potentially enhance sustainability (Kremen et al. 2012). At the same time, this sharpening of the local differences of land use can steepen ecological gradients in ways that incur environmental damage. For example, the continued production of the agrobiodiversity of Andean maize may involve patchiness and reduced areas of cultivation. These changes might modify the frequencies of the highagrobiodiversity landraces or lead to other possibly deleterious effects on the genetic structure and viability of landrace populations. Similarly the tree population dynamics as well as the nutrient and water cycling of smallholder landscapes containing coffee agroforests are a sharp contrast to nearby areas without forests. The actual spatiotemporal grain of patchiness in these 
Table 5. Smallholder social-ecological systems amid telecoupling: summary findings and new insights.

\begin{tabular}{|c|c|c|c|}
\hline Principal Finding & Brief Description & Social-Ecological Insights & Faulty Assumption(s) Eclipsed \\
\hline $\begin{array}{l}\text { Extensive socioeconomic variation } \\
\text { including widespread poverty and } \\
\text { many subject to resource } \\
\text { dispossession }\end{array}$ & $\begin{array}{l}\text { Empirical basis of widespread } \\
\text { livelihood precarity emphasizes the } \\
\text { un-Romantic evaluation of } \\
\text { smallholders }\end{array}$ & $\begin{array}{l}\text { Resource decision making and } \\
\text { management of telecoupled } \\
\text { smallholders varies significantly } \\
\text { within this group }\end{array}$ & $\begin{array}{l}\text { Undifferentiated "peasantry" or } \\
\text { "traditional folk" often assumed } \\
\text { homogeneous, reinforced by } \\
\text { stereotypes }\end{array}$ \\
\hline $\begin{array}{l}\text { Considerable, widespread } \\
\text { integration with markets and } \\
\text { institutions (government, NGO) }\end{array}$ & $\begin{array}{l}\text { Smallholder integration highlights } \\
\text { nonteleological processes of both } \\
\text { persistence and reduced numbers. }\end{array}$ & $\begin{array}{l}\text { Smallholders are dynamic and } \\
\text { responsive to external } \\
\text { circumstances; partial food self- } \\
\text { provisioning key to nutritional } \\
\text { security }\end{array}$ & $\begin{array}{l}\text { Autonomous with exclusive } \\
\text { subsistence orientation; market } \\
\text { integration ensures smallholder } \\
\text { disappearance and erases self- } \\
\text { provisioning }\end{array}$ \\
\hline $\begin{array}{l}\text { Significant telecoupled market } \\
\text { integration through labor, in } \\
\text { addition to land-based commercial } \\
\text { production }\end{array}$ & $\begin{array}{l}\text { Major, continuing expansion of } \\
\text { smallholder non- and off-farm } \\
\text { employment is key to persistence }\end{array}$ & $\begin{array}{l}\text { Part-time farming and resource use, } \\
\text { in addition to migration, are } \\
\text { defining of telecoupled smallholders }\end{array}$ & $\begin{array}{l}\text { "Farmer road" based on full-time } \\
\text { staple food-growing or full-time } \\
\text { urban-based employment are both } \\
\text { eclipsed }\end{array}$ \\
\hline $\begin{array}{l}\text { Wide ranges of levels of } \\
\text { productivity, technology adoption, } \\
\text { and community institutions }\end{array}$ & $\begin{array}{l}\text { Smallholder production can undergo } \\
\text { medium-high levels of agricultural } \\
\text { intensification }\end{array}$ & $\begin{array}{l}\text { Potentially contributes to food } \\
\text { security including technology } \\
\text { adoption and use of community } \\
\text { institutions }\end{array}$ & $\begin{array}{l}\text { Smallholders are nearly always } \\
\text { technologically backward and } \\
\text { inefficient producers }\end{array}$ \\
\hline $\begin{array}{l}\text { Mixed positive and negative } \\
\text { impacts of smallholder } \\
\text { telecoupling on sustainability and } \\
\text { sustainable development }\end{array}$ & $\begin{array}{l}\text { Degree of smallholder sustainability } \\
\text { influenced by conditions } \\
\text { (knowledge, institutions, resource } \\
\text { access) }\end{array}$ & $\begin{array}{l}\text { Smallholder telecoupling potentially } \\
\text { contributes to biodiversity } \\
\text { conservation and sustainable } \\
\text { resource use }\end{array}$ & $\begin{array}{l}\text { Simplistic assumptions (fetishisms) } \\
\text { of smallholders as either ecologically } \\
\text { noble savages or eco-villains }\end{array}$ \\
\hline
\end{tabular}

coffee landscapes depends on biogeophysical gradients, smallholder decision making, resource capacities, and supply chain impacts. In short, future research is needed to determine the ecological dynamics with the complex social-ecological systems of telecoupled smallholders.

The social-ecological integration of biodiversity conservation with food and nutritional security among smallholders has become paramount in global sustainability agendas (Fischer et al. 2012, Jackson et al. 2010, Zimmerer and de Haan 2018). Similarly vital is the integrated pursuit of the goals of global sustainable development (Stafford-Smith et al. 2017), which will require engaging the powerful forces of smallholder telecoupling. The latter exert a major influence on the capacity for increased smallholder income needed to support many goals (Barrett 2008, Barrett et al. 2011). In numerous cases, for example, the income derived from the marketing of biodiversity, or the use of diverse agroecosystems, contributes to combined smallholder food security, health, and ecosystem sustainability, such as coffee agroforests in Colombia (see also Perfecto and Vandermeer 2015) and the soil agroecosystems of organic dairy farmers. Key additional conditions include local cultural and economic valuation as well as resource access.

This positive impact of smallholder telecoupling would potentially extend to nutritionally sensitive ecological intensification (EI) and sustainable intensification (SI; Zimmerer et al. 2015), which both aim to reduce biodiversity loss, lessen net pressure on land, and improve environmental resource management (Lambin et al. 2001). In particular, this study's results argue for the importance of integrating smallholder telecoupling in efforts to improve food and nutritional security in smallholder-based EI (Snapp et al. 2010, Tittonell and Giller 2013, Zimmerer et al. 2015) and SI (Garnett et al. 2013, Loos et al. 2014).
The telecoupling of smallholders also impacts social justice issues involving these populations (Walsh-Dilley et al. 2016). This concern is increasingly recognized as a centerpiece for actionable research on social-ecological systems (Challies et al. 2014, Rudel et al. 2016). Issues of social justice abound in the interactions of telecoupling with issues of environmental resource management in smallholder agroecosystems and landscapes. Ecologists themselves may often be agents in the intersection of smallholder telecoupling and social justice concerns. Many ecological scientists, for example, have become active in both local and global networks promoting sustainable, smallholder-sourced foods and beverages (Perfecto and Vandermeer 2015; e.g., certified fairtrade and organic commodities).

Finally, future research is needed on the rapidly expanding forms of smallholder telecoupling associated with such major global changes as the retail and supermarket revolutions that have transformed agri-food systems worldwide and influenced the production of many small-scale growers (Reardon et al. 2003, 2014, Reardon and Hopkins 2006). Landscape-level and localarea studies have begun to link the transformation of complex local social-ecological systems to these global receiving systems such as the Walmart supermarket chain (Elder and Dauvergne 2015). Yet another important example of smallholder telecoupling involves their responses to receiving systems associated with agricultural technologies such as GMOs/nonGMOs and natural resource management practices, which are already an incipient theme of telecoupling research (Garrett et al. 2013). Distinct yet complementary to the aforementioned focus on commodity linkages is the smallholder telecoupling associated with expanded labor integration (Isakson 2009), with dynamics that may enable sustainability.

In sum the value of applying the framework of smallholder telecoupling to understand sustainability issues is related to 
diverse stakeholders that include a large variety of social actors and institutions. Social-ecological scientists and scholars stand to gain valuable insights related to this perspective. Those focused on such issues as the indicators, population genetics, or seed systems of "traditional agriculture" and "smallholder agroecology" would be well-advised to incorporate the insights of smallholder telecoupling when creating the designs of research and analysis. Similarly, policy makers and social justice proponents will need to consider expanded smallholder telecoupling in their evaluations, program design, and implementation.

\section{CONCLUSIONS: SMALLHOLDER TELECOUPLING AND SUSTAINABILITY INSIGHTS}

The framework of smallholder telecoupling developed to examine potential sustainability opportunities offers several contributions toward actionable research and policy. First, this framework demonstrates utility in strengthening the capacity to understand land and resource use and also livelihoods in relation to the telecoupled linkages of smallholders. Second, it is needed to rethink the earlier ecological categories of "traditional agriculture," "traditional farmers," and "traditional resource users" that in some cases have been seen as mostly or entirely isolated and even autarkic. Our research demonstrates the value of accounting for the realities of current smallholders impacted by global socioeconomic and environmental changes. Third, identifying evidence of potential sustainability benefits of telecoupling is important for reasons of both environmental wellbeing and social justice. Globally, many smallholders face extreme poverty, hardships, and severe livelihood, food, nutritional, and human rights insecurity and violations.

Our findings conclude that major impacts have resulted from smallholder telecoupling. The case studies underscore how modest yet potentially important improvements can be gained in smallholder social-ecological systems and livelihoods. Longitudinal studies across the broad socioeconomic and environmental spectra of these communities will be needed to clarify further these potential benefits and associated risks. Our analysis shows that telecoupled opportunities rarely act alone. In addition to smallholder resources, endowments, and capacities, there is significant influence of national policies and institutions as well as local interactions. The latter include local spillover effects, such as information-sharing and resource coordination. These effects can increase and scale-up the effectiveness of sustainabilityenhancing production, such as organic agriculture (Upper Midwest, USA), food-growing and consumption based on the biodiversity of Andean maize (Bolivia), eco-certification of food products (Colombia), and commercialization of niche commodities based on endemic species (Morocco). Similarly national policies and institutions exert vital influences that mediate telecoupled linkages. Potential positive impacts of labor migration and remittances on sustainability-enhancing land use depends on smallholder tenure rights and involvement of national-level governance.

Our conclusion rests, in addition, on a triad of general findings. First, globally the agroecosystems and landscapes of 2.0-2.5 billion smallholders are not entirely disappearing but rather many are becoming further globalized and connected to distant factors through telecoupling that involves mediating private and public institutions at multiple scales (international, national, local). Second, smallholder telecoupling is quite distinct in relation to large-scale land use with regard to such attributes as spatiotemporal scales, resource levels, and social vulnerability and organization. Smallholder telecoupling also includes distinct levels of capital investments and labor use, communication channels and responsiveness to production signals (e.g., markets, governance), and social access and cultural meaning (e.g., resources, food). Third, these findings help to advance understandings of smallholder social-ecological sustainability within global telecoupling and sustainability analysis. These advances contribute toward overcoming still prevalent views that have tended to oversimplify or even fetishize smallholders as solely the source of ecological problems or rooted in pre- or nonglobal paradigms. Such unfounded stereotypes undermine realistic appraisals of important social-ecological challenges (e.g., food and nutritional security, biodiversity conservation) and potential sustainability opportunities.

Environmental and social justice issues directly affect the majority of the world's smallholder populations. Findings on smallholders involved in the production and consumption of Andean maize biodiversity and the production systems of certified coffee, organic dairy, and argan oil are only a few examples of the global scope of smallholder telecoupling involving important socialecological systems. The extensive and diversified resource activities, environmentally important locations, and socialecological dynamics of telecoupled smallholders, their rights to social justice and social movements, have become vital to the sustainability and resilience of global resource systems and management, the alleviation of poverty and food-nutritional insecurity through income enhancement and robust food systems, and the potential for socioeconomically beneficial and ecologically sound livelihood diversification.

\section{Responses to this article can be read online at: http://www.ecologyandsociety.org/issues/responses. $\mathrm{php} / 9935$}

\begin{abstract}
Acknowledgments:
Field research in the Bolivia and Wisconsin case studies in phase I (2002-2005) and phase II (2007-1012) were funded through National Science Foundation Grant BC 0240962 (University of Wisconsin-Madison) and National Science Foundation Grant HSD $0948816 \quad$ (Pennsylvania State University). Research collaborations with Brad Barham, Dave Lewis, Luís Rojas, Russell Hedberg, Judith Carney, James Burt, Amy Burnicki, and Travis Tennessen were important to this work. The first author drafted a short version of this paper in fall 2012 and gratefully acknowledges the feedback at its presentation in organized sessions at the 2013 meetings of the Association of American Geographers in Los Angeles. Subsequent full collaboration of the team of authors and productive exchanges occurred in conjunction with the meetings of the Global Land Change Project (2014, 2016), the Ecological Society of America (2016), and the U.S. Regional Association for the International Association for Landscape Ecology (2017) as well as presentation to the Forestry and Environmental Studies
\end{abstract}


program at Yale University (2016). The helpful comments of Tom Crist, Jack Liu, Karen Seto, Ruth DeFries, Billie Lee Turner, Kendra McSweeney, Hallie Eakin, and Amy Lerner are gratefully acknowledged. Three anonymous reviewers and the editors of the special feature provided helpful inputs.

\section{LITERATURE CITED}

Adger, W. N., H. Eakin, and A. Winkels. 2009. Nested and teleconnected vulnerabilities to environmental change. Frontiers in Ecology and the Environment 7(3):150-157. http://dx.doi. org/10.1890/070148

Aker, J. C., and I. M. Mbiti. 2010. Mobile phones and economic development in Africa. Journal of Economic Perspectives 24 (3):207-232. http://dx.doi.org/10.1257/jep.24.3.207

Aide, T. M., and H. R. Grau. 2004. Globalization, migration, and Latin American ecosystems. Science 305(5692):1915-1916. http:// dx.doi.org/10.1126/science. 1103179

Altieri, M. A. 2004. Linking ecologists and traditional farmers in the search for sustainable agriculture. Frontiers in Ecology and the Environment 2(1):35-42. http://dx.doi.org/10.1890/1540-9295 (2004)002[0035:LEATFI]2.0.CO;2

Altieri, M. A., C. I. Nicholls, A. Henao, and M. A. Lana. 2015. Agroecology and the design of climate change-resilient farming systems. Agronomy for Sustainable Development 35(3):869-890. http://dx.doi.org/10.1007/s13593-015-0285-2

Baird, I. G. 2017. Resistance and contingent contestations to large-scale land concessions in southern Laos and northeastern Cambodia. Land 6(1):16. http://dx.doi.org/10.3390/land6010016

Baird, I. G., and J. Fox. 2015. How land concessions affect places elsewhere: telecoupling, political ecology, and large-scale plantations in southern Laos and northeastern Cambodia. Land 4(2):436-453. http://dx.doi.org/10.3390/land4020436

Barrett, C. B. 2008. Smallholder market participation: concepts and evidence from eastern and southern Africa. Food Policy 33 (4):299-317. http://dx.doi.org/10.1016/j.foodpol.2007.10.005

Barrett, C. B., A. J. Travis, and P. Dasgupta. 2011. On biodiversity conservation and poverty traps. Proceedings of the National Academy of Sciences 108(34):13907-13912. http://dx.doi. org/10.1073/pnas.1011521108

Bebbington, A. J., and S. P. J. Batterbury. 2001. Transnational livelihoods and landscapes: political ecologies of globalization. Cultural Geography 8:369-380.

Berdigué, J. A., and R. Fuentealba. 2011. The state of smallholders in agriculture in Latin America. Pages 115-154 in P. B. R. Hazell and A. Rahman, editors. New directions for smallholder agriculture. Oxford University Press, Oxford, UK. http://dx.doi.org/10.1093/acprof:oso/9780199689347.003.0005

Brondizio, E. S., K. O’Brien, X. Bai, F. Biermann, W. Steffen, F. Berkhout, C. Cudennec, M. C. Lemos, A. Wolfe, J. PalmaOliviera, and C.-T. A. Chen. 2016. Re-conceptualizing the Anthropocene: a call for collaboration. Global Environmental Change 39:318-327. http://dx.doi.org/10.1016/j.gloenvcha.2016.02.006
Brookfield, H. C. 2001. Exploring agrodiversity. Columbia University Press, New York, New York, USA. http://dx.doi. org/10.7312/broo 10232

Cárdenas, J. C., M. A. Janssen, M. Ale, R. Bastakoti, A. Bernal, J. Chalermphol, Y. Gong, H. Shin, G. Shivakoti, Y. Wang, and J. M. Anderies. 2017. Fragility of the provision of local public goods to private and collective risks. Proceedings of the National Academy of Sciences 114(5):921-925. http://dx.doi.org/10.1073/ pnas. 1614892114

Carr, D. 2009. Population and deforestation: why rural migration matters. Progress in Human Geography 33(3):355-378. http://dx. doi.org/10.1177/0309132508096031

Castles, S., H. de Haas, and M. J. Miller. 2013. The age of migration: international population movements in the modern world. Palgrave Macmillan, London, UK.

Central Intelligence Agency (CIA). 2014. The world factbook. CIA, Washington, D.C., USA. [online] URL: https://www.cia. gov/library/publications/download/download-2014/index.html

Central Intelligence Agency (CIA). 2017. The world factbook. CIA, Washington, D.C., USA. [online] URL: https://www.cia. gov/library/publications/the-world-factbook/rankorder/rankorderguide. $\underline{\mathrm{html}}$

Challies, E. R. T. 2008. Commodity chains, rural development and the global agri-food system. Geography Compass 2 (2):375-394. http://dx.doi.org/10.1111/j.1749-8198.2008.00095.x

Challies, E., J. Newig, and A. Lenschow. 2014. What role for social-ecological systems research in governing global teleconnections? Global Environmental Change 27:32-40. http:// dx.doi.org/10.1016/j.gloenvcha.2014.04.015

Clark, W. C., T. P. Tomich, M. Van Noordwijk, D. Guston, D. Catacutan, N. M. Dickson, and E. McNie. 2016. Boundary work for sustainable development: natural resource management at the Consultative Group on International Agricultural Research (CGIAR). Proceedings of the National Academy of Sciences 113 (17):4615-4622. http://dx.doi.org/10.1073/pnas.0900231108

Cohn, A. S., P. Newton, J. D. B. Gil, L. Kuhl, L. Samberg, V. Ricciardi, J. R. Manly, and S. Northrop. 2017. Smallholder agriculture and climate change. Annual Review of Environment and Resources 42:347-375. http://dx.doi.org/10.1146/annurevenviron-102016-060946

Cumming, G. S., P. Olsson, F. S. Chapin III, and C. S. Holling. 2013. Resilience, experimentation, and scale mismatches in socialecological landscapes. Landscape Ecology 28(6):1139-1150. http://dx.doi.org/10.1007/s10980-012-9725-4

Darnhofer, I. 2014. Resilience and why it matters for farm management. European Review of Agricultural Economics 41 (3):461-484. http://dx.doi.org/10.1093/erae/jbu012

Darnhofer, I., C. Lamine, A. Strauss, and M. Navarrete. 2016. The resilience of family farms: towards a relational approach. Journal of Rural Studies 44:111-122. http://dx.doi.org/10.1016/j. jrurstud.2016.01.013 
de Haas, H. 2006. Migration, remittances and regional development in southern Morocco. Geoforum 37(4):565-580. http://dx.doi.org/10.1016/j.geoforum.2005.11.007

DeFries, R., M. Herold, L. Verchot, M. N. Macedo, and Y. Shimabukuro. 2013. Export-oriented deforestation in Mato Grosso: harbinger or exception for other tropical forests? Philosophical Transactions of the Royal Society of London B: Biological Sciences 368(1619):20120173. http://dx.doi.org/10.1098/ $\underline{\text { rstb. } 2012.0173}$

Dragusanu, R., D. Giovannucci, and N. Nunn. 2014. The economics of fair trade. Journal of Economic Perspectives 28 (3):217-236. http://dx.doi.org/10.1257/jep.28.3.217

Eakin, H., R. DeFries, S. Kerr, E. F. Lambin, J. Liu, P. J. Marcotullio, P. Messerli, A. Reenberg, X. Rueda, S. R. Swaffield, B. Wicke, and K. S. Zimmerer. 2014. Significance of telecoupling for exploration of land use change. Pages 141-162 in K. Seto and A. Reenberg, editors. Rethinking global land use in an urban era. MIT Press, Cambridge, Massachusetts, USA. http://dx.doi. org $/ 10.7551 / \mathrm{mitpress} / 9780262026901.003 .0008$

Elder, S. D., and P. Dauvergne. 2015. Farming for Walmart: the politics of corporate control and responsibility in the Global South. Journal of Peasant Studies 42(5):1029-1046. http://dx.doi. org/10.1080/03066150.2015.1043275

Ellis, F. 1998. Household strategies and rural livelihood diversification. Journal of Development Studies 35(1):1-38. http:// dx.doi.org/10.1080/00220389808422553

Fischer, J., T. Hartel, and T. Kuemmerle. 2012. Conservation policy in traditional farming landscapes. Conservation Letters 5 (3):167-175. http://dx.doi.org/10.1111/j.1755-263X.2012.00227. $\underline{\mathrm{X}}$

Freidberg, S. 2004. French beans and food scares: culture and commerce in an anxious age. Oxford University Press, Oxford, UK.

Friis, C., and J. Ø. Nielsen. 2016. Small-scale land acquisitions, large-scale implications: exploring the case of Chinese banana investments in northern Laos. Land Use Policy 57:117-129. http:// dx.doi.org/10.1016/j.landusepol.2016.05.028

Friis, C., and J. Ø. Nielsen. 2017. Land-use change in a telecoupled world: the relevance and applicability of the telecoupling framework in the case of banana plantation expansion in Laos. Ecology and Society 22(4):30. http://dx.doi.org/10.5751/ ES-09480-220430

Friis, C., J. Ø. Nielsen, I. Otero, H. Haberl, J. Niewöhner, and P. Hostert. 2016a. From teleconnection to telecoupling: taking stock of an emerging framework in land system science. Journal Land Use Science 11(2):131-153. http://dx.doi.org/10.1080/1747423X.2015 .1096423

Friis, C., A. Reenberg, A. Heinimann, and O. Schönweger. $2016 b$. Changing local land systems: implications of a Chinese rubber plantation in Nambak District, Lao PDR. Singapore Journal of Tropical Geography 37(1):25-42. http://dx.doi.org/10.1111/ sjtg. 12137

Garnett T., M. C. Appleby, A. Balmford, I. J. Bateman, T. G. Benton, P. Bloomer, B. Burlingame, M. Dawkins, L. Dolan, D.
Fraser, et al. 2013. Sustainable intensification in agriculture: premises and policies. Science 341:33-34. http://dx.doi. org/10.1126/science.1234485

Garrett, R. D., X. Rueda, and E. F. Lambin. 2013. Globalization's unexpected impact on soybean production in South America: linkages between preferences for non-genetically modified crops, eco-certifications, and land use. Environmental Research Letters 8(4):044055. http://dx.doi.org/10.1088/1748-9326/8/4/044055

Gasparri, N. I., T. Kuemmerle, P. Meyfroidt, Y. le Polain de Waroux, and H. Kreft. 2016. The emerging soybean production frontier in Southern Africa: conservation challenges and the role of south-south telecouplings. Conservation Letters 9(1):21-31. http://dx.doi.org/10.1111/conl.12173

Giller, K. E., P. Tittonell, M. C. Rufino, M. T. van Wijk, S. Zingore, P. Mapfumo, S. Adjei-Nsiah, M. Herrero, R. Chikowo, M. Corbeels, et al. 2011. Communicating complexity: integrated assessment of trade-offs concerning soil fertility management within African farming systems to support innovation and development. Agricultural Systems 104:191-203. http://dx.doi. org/10.1016/j.agsy.2010.07.002

Graeub, B. E., M. J. Chappell, H. Wittman, S. Ledermann, R. Bezner Kerr, and B. Gemmill-Herren. 2016. The state of family farms in the world. World Development 87:1-15. http://dx.doi. org/10.1016/j.worlddev.2015.05.012

Gray, C. L. 2009. Rural out-migration and smallholder agriculture in the southern Ecuadorian Andes. Population and Environment 30:193-217. http://dx.doi.org/10.1007/s11111-009-0081-5

Herrero, M., P. K. Thornton, B. Power, J. R. Bogard, R. Remans, S. Fritz, J. S. Gerber, G. Nelson, L. See, K. Waha, et al. 2017. Farming and the geography of nutrient production for human use: a transdisciplinary analysis. Lancet Planetary Health 1(1): e33-e42. http://dx.doi.org/10.1016/S2542-5196(17)30007-4

High Level Panel of Experts (HLPE). 2013. Investing in smallholder agriculture for food security. A report of the HLPE on Food Security and Nutrition of the Committee on World Food Security. Food and Agriculture Organization, Rome, Italy.

International Fund for Agricultural Development (IFAD). 2013. Investing in smallholder family agriculture for global food security and nutrition. Post-2015 Policy Brief 3. IFAD, Rome, Italy.

Isakson, S. R., 2009. No hay ganancia en la milpa: the agrarian question, food sovereignty, and the on-farm conservation of agrobiodiversity in the Guatemalan highlands. Journal of Peasant Studies 36(4):725-759. http://dx.doi.org/10.1080/03066150903353876

Jackson L., M. van Noordwijk, J. Bengtsson, W. Foster, L. Lipper, M. Pulleman, M. Said, J. Snaddon, and R. Vodouhe. 2010. Biodiversity and agricultural sustainagility: from assessment to adaptive management. Current Opinion in Environmental Sustainability 2:80-87. http://dx.doi.org/10.1016/j.cosust.2010.02.007

Jones, R. C. 1998. Introduction: the renewed role of remittances in the new world order. Economic Geography 74(1):1-7. http://dx. doi.org/10.2307/144340

Kissinger, M., W. E. Rees, and V. Timmer. 2011. Interregional sustainability: governance and policy in an ecologically interdependent world. Environmental Science \& Policy 14 (8):965-976. http://dx.doi.org/10.1016/j.envsci.2011.05.007 
Kok, M. T. J., K. Kok, G. D. Peterson, R. Hill, J. Agard, and S. R. Carpenter. 2017. Biodiversity and ecosystem services require IPBES to take novel approach to scenarios. Sustainability Science 12(1):177-181. http://dx.doi.org/10.1007/s11625-016-0354-8

Kremen, C., A. Iles, and C. Bacon. 2012. Diversified farming systems: an agroecological, systems-based alternative to modern industrial agriculture. Ecology and Society 17(4):44. http://dx.doi. org/10.5751/ES-05103-170444

Lambin, E. F., and P. Meyfroidt. 2011. Global land use change, economic globalization, and the looming land scarcity. Proceedings of the National Academy of Science 108:3465-3472. http://dx.doi.org/10.1073/pnas.1100480108

Lambin, E. F., B. L. Turner, H. J. Geist, S. B. Agbola, A. Angelsen, J. W. Bruce, O. T. Coomes, R. Dirzo, G. Fischer, C. Folke, et al. 2001. The causes of land-use and land-cover change: moving beyond the myths. Global Environmental Change 11:261-269. http://dx.doi.org/10.1016/S0959-3780(01)00007-3

le Polain de Waroux, Y., and E. F. Lambin. 2012. Monitoring degradation in arid and semi-arid forests and woodlands: the case of the argan woodlands (Morocco). Applied Geography 32:777-786. http://dx.doi.org/10.1016/j.apgeog.2011.08.005

le Polain de Waroux, Y., and E. F. Lambin. 2013. Niche commodities and rural poverty alleviation: contextualizing the contribution of argan oil to rural livelihoods in Morocco. Annals of Association of American Geographers 103(3):589-607. http:// dx.doi.org/10.1080/00045608.2012.720234

Lenschow, A., J. Newig, and E. Challies. 2016. Globalization's limits to the environmental state? Integrating telecoupling into global environmental governance. Environmental Politics 25 (1):136-159. http://dx.doi.org/10.1080/09644016.2015.1074384

Lerner, A. M., and H. Eakin. 2011. An obsolete dichotomy? Rethinking the rural-urban interface in terms of food security and production in the global south. Geography Journal 177:311-320. http://dx.doi.org/10.1111/j.1475-4959.2010.00394. $\underline{\mathrm{X}}$

Lewis, D. J., B. L. Barham, and B. Robinson. 2011. Are there spatial spillovers in the adoption of clean technology? The case of organic dairy farming. Land Economics 87(2):250-267. http:// dx.doi.org/10.3368/le.87.2.250

Lewis, D. J., B. L. Barham, and K. S. Zimmerer. 2008. Spatial externalities in agriculture: empirical analysis, statistical identification, and policy implications. World Development 36 (10):1813-1829. http://dx.doi.org/10.1016/j.worlddev.2007.10.017

Liu, J., V. Hull, M. Batistella, R. DeFries, T. Dietz, F. Fu, T. W. Hertel, R. C. Izaurralde, E. F. Lambin, S. Li, L. A. Martinelli, W. J. McConnell, E. F. Moran, R. Naylor, Z. Ouyang, K. R. Polenske, A. Reenberg, G. de Miranda Rocha, C. S. Simmons, P. H. Verburg, P. M. Vitousek, F. Zhang, and C. Zhu. 2013. Framing sustainability in a telecoupled world. Ecology and Society 18 (2):26. http://dx.doi.org/10.5751/ES-05873-180226

Liu, J., V. Hull, J. Luo, W. Yang, W. Liu, A. Viña, C. Vogt, Z. Xu, H. Yang, J. Zhang, L. An, X. Chen, S. Li, Z. Ouyang, W. Xu and H. Zhang. 2015. Multiple telecouplings and their complex interrelationships. Ecology and Society 20(3):44. http://dx.doi. org/10.5751/ES-07868-200344
Loos, J., D. J. Abson, M. J. Chappell, J. Hanspach, F. Mikulcak, M. Tichit, and J. Fischer. 2014. Putting meaning back into "sustainable intensification." Frontiers in Ecology and the Environment 12(6):356-361. http://dx.doi.org/10.1890/130157

Lowder, S. K., J. Skoet, and T. Raney. 2016. The number, size, and distribution of farms, smallholder farms, and family farms worldwide. World Development 87:16-29. http://dx.doi.org/10.1016/ j.worlddev.2015.10.041

Lybbert, T. J., A. Aboudrare, D. Chaloud, N. Magnan, and M. Nash. 2011. Booming markets for Moroccan argan oil appear to benefit some rural households while threatening the endemic argan forest. Proceedings of the National Academy of Sciences 108 (34):13963-13968. http://dx.doi.org/10.1073/pnas.1106382108

Lybbert, T., C. B. Barrett, and H. Narjisse. 2004. Does resource commercialization induce local conservation? A cautionary tale from southwestern Morocco. Society \& Natural Resources 17 (5):413-430. http://dx.doi.org/10.1080/08941920490430205

Meyfroidt, P. 2017. Mapping farm size globally: benchmarking the smallholders debate. Environmental Research Letters 12 (3):031002. http://dx.doi.org/10.1088/1748-9326/aa5ef6

Meyfroidt, P., E. F. Lambin, K.-H. Erb, T. W. Hertel. 2013. Globalization of land use: distant drivers of land change and geographic displacement of land use. Current Opinions in Environmental Sustainability 5:438-444. http://dx.doi.org/10.1016/ j.cosust.2013.04.003

Moseley, W. G. 2016. Agriculture on the brink: climate change, labor and smallholder farming in Botswana. Land 5(3):21. http:// dx.doi.org/10.3390/land5030021

Müller, D., and D. K. Munroe. 2014. Current and future challenges in land-use science. Journal of Land Use Science 9 (2):133-142. http://dx.doi.org/10.1080/1747423X.2014.883731

Munroe, D. K., K. McSweeney, J. L. Olson, and B. Mansfield. 2014. Using economic geography to reinvigorate land-change science. Geoforum 52:12-21. http://dx.doi.org/10.1016/j. geoforum.2013.12.005

Mutersbaugh, T. 2006. Certifying biodiversity: conservation networks, landscape connectivity, and certified agriculture in southern Mexico. Pages 49-70 in K. S. Zimmerer, editor. Globalization and new geographies of conservation. University of Chicago Press, Chicago, Illinois, USA.

Netting, R. M. 1993. Smallholders, householders: farm families and the ecology of intensive, sustainable agriculture. Stanford University Press, Palo Alto, California, USA.

Nilsen, L. B., A. Subedi, M. E. Dulloo, K. Ghosh, J. ChavezTafur, G. M. B. Canto, and W. S. de Boef. 2015. Practices and networks supporting the on-farm management of plant genetic resources for food and agriculture. Plant Genetic Resources 13 (1):36-44. http://dx.doi.org/10.1017/S1479262114000616

Ostrom, E. 2009. A general framework for analyzing sustainability of social-ecological systems. Science 325 (5939):419-422. http://dx.doi.org/10.1126/science.1172133

Parker, D. C., and D. K. Munroe. 2007. The geography of market failure: edge-effect externalities and the location and production 
patterns of organic farming. Ecological Economics 60(4):821-833. http://dx.doi.org/10.1016/j.ecolecon.2006.02.002

Perfecto, I., and J. Vandermeer. 2002. Quality of agroecological matrix in a tropical montane landscape: ants in coffee plantations in southern Mexico. Conservation Biology 16:174-182. http://dx. doi.org/10.1046/j.1523-1739.2002.99536.x

Perfecto, I., and J. Vandermeer. 2015. Coffee agroecology: a new approach to understanding agricultural biodiversity, ecosystem services and sustainable development. Routledge, London, UK.

Plieninger, T., and C. Bieling, editors. 2012. Resilience and the cultural landscape: understanding and managing change in humanshaped environments. Cambridge University Press, Cambridge, UK. http://dx.doi.org/10.1017/CBO9781139107778

Radel, C., and D. L. Coppock. 2013. The world's gender gap in agriculture and natural resources: evidence and explanations. Rangelands 35(6):7-14. http://dx.doi.org/10.2111/RANGELANDSD-13-00036.1

Radel, C., B. Schmook, and S. McCandless. 2010. Environment, transnational labor migration, and gender: case studies from southern Yucatan, Mexico and Vermont, USA. Population and Environment 32(2-3):177-197. http://dx.doi.org/10.1007/s11111-010-0124y

Reardon, T. 1997. Using evidence of household income diversification to inform study of the rural nonfarm labor market in Africa. World Development 25(5):735-747. http://dx.doi. org/10.1016/S0305-750X(96)00137-4

Reardon, T., K. Z. Chen, B. Minten, L. Adriano, T. A. Dao, J. Wang, and S. D. Gupta. 2014. The quiet revolution in Asia's rice value chains. Annals of the New York Academy of Sciences 1331:106-118. http://dx.doi.org/10.1111/nyas.12391

Reardon, T., and R. Hopkins. 2006. The supermarket revolution in developing countries: policies to address emerging tensions among supermarkets, suppliers and traditional retailers. European Journal of Development Research 18(4):522-545.

Reardon, T., C. P. Timmer, C. B. Barrett, and J. Berdegué. 2003. The rise of supermarkets in Africa, Asia, and Latin America. American Journal of Agricultural Economics 85(5):1140-1146. http://dx.doi.org/10.1111/j.0092-5853.2003.00520.x

Rudel, T. K., O. T. Coomes, E. Moran, F. Achard, A. Angelsen, J. Xu, and E. Lambin. 2005. Forest transitions: towards a global understanding of land use change. Global Environmental Change 15(1):23-31. http://dx.doi.org/10.1016/i.gloenvcha.2004.11.001

Rudel, T. K., O.-J. Kwon, B. K. Paul, M. Boval, I. M. Rao, D. Burbano, M. McGroddy, A. M. Lerner, D. White, M. Cuchillo, M. Luna, and M. Peters. 2016. Do smallholder, mixed croplivestock livelihoods encourage sustainable agricultural practices? A meta-analysis. Land 5(1):6. http://dx.doi.org/10.3390/ land5010006

Rudel, T. K, and P. Meyfroidt. 2014. Organizing anarchy: the food security-biodiversity-climate crisis and the genesis of rural land use planning in the developing world. Land Use Policy 36:239-247. http://dx.doi.org/10.1016/j.landusepol.2013.07.008

Rueda, X., and E. F. Lambin. 2013a. Linking globalization to local land uses: how eco-consumers and gourmands are changing the Colombian coffee landscapes. World Development 41:286-301. http://dx.doi.org/10.1016/j.worlddev.2012.05.018

Rueda, X., and E. F. Lambin. 2013b. Responding to globalization: impacts of certification on Colombian small-scale coffee growers. Ecology and Society 18(3):21. http://dx.doi.org/10.5751/ ES-05595-180321

Rueda, X., N. E. Thomas, and E. F. Lambin. 2015. Ecocertification and coffee cultivation enhance tree cover and forest connectivity in the Colombian coffee landscapes. Regional Environmental Change 15(1):25-33. http://dx.doi.org/10.1007/ s10113-014-0607-y

Samberg, L. H., J. S. Gerber, N. Ramankutty, M. Herrero, and P. C. West. 2016. Subnational distribution of average farm size and smallholder contributions to global food production. Environmental Research Letters 11(12):124010. http://dx.doi. org/10.1088/1748-9326/11/12/124010

Schaffartzik, A., A. Brad, M. Pichler, and C. Plank. 2016. At a distance from the territory: distal drivers in the (re) territorialization of oil palm plantations in Indonesia. Pages 41-57 in J. Niewöhner, A. Bruns, P. Hostert, T. Krueger, J. Ø Nielsen, H. Haberl, C. Lauk, J. Lutz, and D. Müller, editors. Land use competition: ecological, economic and social perspectives Springer, Berlin, Germany. http://dx.doi.org/10.1007/978-3-319-33628-2_3

Seto, K. C., and N. Ramankutty. 2016. Hidden linkages between urbanization and food systems. Science 352(6288):943-945. http:// dx.doi.org/10.1126/science.aaf7439

Seto, K. C., A. Reenberg, C. G. Boone, M. Fragkias, D. Haase, T. Langanke, P. Marcotullio, D. K. Munroe, B. Olah, and D. Simon. 2012. Urban land teleconnections and sustainability. Proceedings of the National Academy of Sciences 109 (20):7687-7692. http://dx.doi.org/10.1073/pnas.1117622109

Seto, K. C., R. Sánchez-Rodríguez, and M. Fragkias. 2010. The new geography of contemporary urbanization and the environment. Annual Review of Environment and Resources 35:167-194. http://dx.doi.org/10.1146/annurev-environ-100809-125336

Snapp, S. S., M. J. Blackie, R. A. Gilbert, and G. Y. KanyamaPhiri. 2010. Biodiversity can support a greener revolution in Africa. Proceedings of the National Academy of Sciences 107:20840-20845. http://dx.doi.org/10.1073/pnas.1007199107

Stafford-Smith, M., D. Griggs, O. Gaffney, F. Ullah, B. Reyers, N. Kanie, B. Stigson, P. Shrivastava, M. Leach, and D. O'Connell. 2017. Integration: the key to implementing the sustainable development goals. Sustainability Science 12(6):911-919. http:// dx.doi.org/10.1007/s11625-016-0383-3

Suri, T., W. Jack, and T. M. Stoker. 2012. Documenting the birth of a financial economy. Proceedings of the National Academy of Sciences 109(26):10257-10262. http://dx.doi.org/10.1073/pnas.1115843109

Sun, J., Y. Tong, and J. Liu. 2017. Telecoupled land-use changes in distant countries. Journal of Integrative Agriculture 16 (2):368-376. http://dx.doi.org/10.1016/S2095-3119(16)61528-9

Thebo, A. L., P. Drechsel, and E. F. Lambin. 2014. Global assessment of urban and peri-urban agriculture: irrigated and rainfed croplands. Environmental Research Letters 9:114002. http://dx.doi.org/10.1088/1748-9326/9/11/114002 
Tittonell, P., and K. E. Giller. 2013. When yield gaps are poverty traps: the paradigm of ecological intensification in African smallholder agriculture. Field Crops Research 143:76-90. http:// dx.doi.org/10.1016/j.fcr.2012.10.007

Tscharntke, T., Y. Clough, T. C. Wanger, L. Jackson, I. Motzke, I. Perfecto, J. Vandermeer, and A. Whitbread. 2012. Global food security, biodiversity conservation and the future of agricultural intensification. Biological Conservation 151(1):53-59. http://dx. doi.org/10.1016/j.biocon.2012.01.068

Turner, B. L. 1997. The sustainability principle in global agendas: implications for understanding land-use/cover change. Geographical Journal 163:133-140. http://dx.doi.org/10.2307/3060176

Turner, B. L. II, and S. B. Brush, editors. 1987. Comparative farming systems. Guilford Press, New York, New York, USA.

Vadjunec, J. M., C. Radel, and B. L. Turner II. 2016. Introduction: the continued importance of smallholders today. Land 5(4):34. http://dx.doi.org/10.3390/land5040034

van Vliet, J. A., A. G. T. Schut, P. Reidsma, K. Descheemaeker, M. Slingerland, G. W. J. van de Ven, and K. E. Giller. 2015. Demystifying family farming: features, diversity and trends across the globe. Global Food Security 5:11-18. http://dx.doi. org/10.1016/j.gfs.2015.03.001

Verburg, P. H., N. Crossman, E. C. Ellis, A. Heinimann, P. Hostert, O. Mertz, H. Nagendra, T. Sikor, K.-H. Erb, N. Golubiewski, et al. 2015. Land system science and sustainable development of the earth system: a global land project perspective. Anthropocene 12:29-41. http://dx.doi.org/10.1016/j. ancene.2015.09.004

Vorley, B. 2001. The chains of agriculture: sustainability and the restructuring of agri-food markets. International Institute for Environment and Development, London, UK.

Walsh-Dilley, M., W. Wolford, and J. McCarthy. 2016. Rights for resilience: food sovereignty, power, and resilience in development practice. Ecology and Society 21(1):11. http://dx.doi.org/10.5751/ ES-07981-210111

Wolford, W., S. M. Borras Jr, R. Hall, I. Scoones, and B. White. 2013. Governing global land deals: the role of the state in the rush for land. Development and Change 44(2):189-210. http://dx.doi. org/10.1111/dech.12017

Wollni, M., and C. Andersson. 2014. Spatial patterns of organic agriculture adoption: evidence from Honduras. Ecological Economics 97:120-128. http://dx.doi.org/10.1016/j.ecolecon.2013.11.010

Woods, M. 2007. Engaging the global countryside: globalization, hybridity and the reconstitution of rural place. Progress in Human Geography 31(4):485-507. http://dx.doi.org/10.1177/0309132507079503

World Bank. 2014. Population, total. The World Bank, Washington, D.C., USA. [online] URL: https://data.worldbank. org/indicator/SP.POP.TOTL

World Bank. 2017a. Brief: migration and remittances data. The World Bank, Washington, D.C., USA. [online] URL: http://www. worldbank.org/en/topic/migrationremittancesdiasporaissues/brief/ migration-remittances-data

World Bank. 2017b. Net official development assistance and official aid received. The World Bank, Washington, D.C., USA. [online]

\section{URL: $\underline{\text { https://data.worldbank.org/indicator/DT.ODA.ALLD.CD }}$}

Zimmerer, K. S. 2004. Cultural ecology: placing households in human-environment studies-the cases of tropical forest transitions and agrobiodiversity change. Progress in Human Geography 28(6):795-806. http://dx.doi.org/10.1191/0309132504ph520pr

Zimmerer, K. S., editor. 2006. Globalization and new geographies of conservation. University of Chicago Press, Chicago, Illinois, USA.

Zimmerer, K. S. 2013. The compatibility of agricultural intensification in a global hotspot of smallholder agrobiodiversity (Bolivia). Proceedings of the National Academy of Sciences 110:2769-2774. http://dx.doi.org/10.1073/pnas.1216294110

Zimmerer, K. S. 2014. Conserving agrobiodiversity amid global change, migration, and nontraditional livelihood networks: the dynamic uses of cultural landscape knowledge. Ecology and Society 19(2):1. http://dx.doi.org/10.5751/ES-06316-190201

Zimmerer, K. S. 2017. Bridging new sustainable development goals: global agendas and landscape stewardship. Pages 311-331 in $\mathrm{C}$. Bieling and T. Plieninger, editors. The science and practice of landscape stewardship. Cambridge University Press, Cambridge, UK. http://dx.doi.org/10.1017/9781316499016.031

Zimmerer, K. S. 2018. Crisis or potential sustainability? Agrobiodiversity and agri-food systems in the Anthropocene. Anthropocene, in press.

Zimmerer, K. S., and J. C. Carney. 2018. How do demographic change and spatial integration interact with agrobiodiversity? In Agrobiodiversity in the 21st century: integrative knowledge and sustainability. K. S. Zimmerer and S. de Haan, editors. MIT Press, Cambridge, Massachusetts, USA, in press.

Zimmerer, K. S., J. A. Carney, and S. J. Vanek. 2015. Sustainable smallholder intensification in global change? Pivotal spatial interactions, gendered livelihoods, and agrobiodiversity. Current Opinion in Environmental Sustainability 14:49-60. http://dx.doi. org/10.1016/j.cosust.2015.03.004

Zimmerer, K. S., and S. de Haan. 2017. Agrobiodiversity and a sustainable food future. Nature Plants 3(1):1-3. http://dx.doi. org/10.1038/nplants.2017.47

Zimmerer, K. S., and S. de Haan, editors. 2018. Agrobiodiversity in the 21st century: integrative knowledge and sustainability. MIT Press, Cambridge, Massachusetts, USA, in press.

Zimmerer, K. S., and H. L. Rojas Vaca. 2016. Fine-grain spatial patterning and dynamics of land use and agrobiodiversity amid global changes in the Bolivian Andes. Regional Environmental Change 16(8):2199-2214. http://dx.doi.org/10.1007/s10113-015-0897-8

Zimmerer, K. S., and S. J. Vanek. 2016. Toward the integrated framework analysis of linkages among agrobiodiversity, livelihood diversification, ecological systems, and sustainability amid global change. Land 5(2):10. http://dx.doi.org/10.3390/ $\underline{\text { land } 5020010}$ 